Çanakkale Araştırmaları Türk Yıllığı

Yll: 13, Bahar 2015, Sayı: 18, ss. 465-505, 100. Yll

\title{
Harb-i Umumi, Eğitim ve Toplum: Bir Neslin Yok Oluşu
}

\section{Mustafa SELÇUK"}

$\ddot{O} z$

Milyonlarca insanın ölümüne ve yaralanmasına neden olan Cihan Harbi, aynı zamanda siyasi, askeri, iktisadi ve içtimai etkileri günümüze kadar devam eden büyük bir felaket olarak kayıtlara geçmiştir. Bu savaşın Osmanlı eğitim sistemine etkileri, Çanakkale Savaşları ve İstanbul'daki yükseköğretim kurumları üzerinden incelenmesi hedeflenmektedir. Çalışmamızda Osmanlı seferberliği süresince ordunun ihtiyaçlarının karşılanması ve savaşın idamesi konusunda maarif teșkilatının faaliyetleri ele alınmıştır. Makalede Osmanlı arşiv belgeleri, ikinci kaynaklar kullanılmıştır.

Anahtar Kelimeler: Harp, Maarif, İstanbul, Çanakkale Muharebeleri, Öğrenciler

Great War, Education and Society: Destruction of a Generation

\begin{abstract}
World War which caused death and injury of millions was also recorded as a great debacle that has ongoing political, military, economic and social affects. The effects of this war on Ottoman educational system are aimed to be examined on the higher institutes at Istanbul and Çanakkale (Gallipoli) battles. Activities of educational ministry about supplying the needs of army and maintenance of war during the Ottoman mobilization are surveyed in our study. The Ottoman Archive documents and secondary sources were used at the essay.

Keywords: War, Educational, İstanbul, Çanakkale (Gallipoli) Battles, Students
\end{abstract}

Doç. Dr., İstanbul Üniversitesi, Edebiyat Fakültesi, Tarih Bölümü, mustafasell@gmail.com. 
"Şu hukuk tahsilim hep kara günler içinde geçiyor. İlk girdiğim sene Balkan Harbi çıktı. Onun kargaşası arasında ilk iki sınıfı bitirdim. Imtihanların akabinde seferberlik ve sonra harp. Dört buçuk seneye yakın harp. Mağlup olduk. Mütareke dirıltıları arasında İstanbul'un işgali yetmiyormuş gibi Adana'nın ve şimdi de İzmir'in işgali. Ve bu belalar arasında üniversite tahsili. Ne karışık ve karanlık şans."

\section{Hakkı Sunata ${ }^{1}$}

"Louvain şehri [Belçika], harikulade kiliseleriyle, eski evleriyle, dillere destan gotik tarzdaki hükümet konağıyla ve 1425'te kurulmuş üniversitesiyle tanınan bir yerdi. Kampüsteki tarihi Cloth Hall binasında bulunan üniversite kütüphanesinde 200.000'i aşkın sayıda değerli ilahiyat çalışmasının ve klasiklerin yanı sıra zengin koleksiyonu bulunmaktaydı. Ancak 1914 Ağustos'unun sonlarında havay bir duman kokusu kaplarken Louvain' saran alevler kilometrelerce uzaktan görülebiliyordu. (...) Insanlar kaçmaya çalışırken, kentin büyük bölümü zengin kütüphanesi de yok olup gitti. Belçika'nın çoğu kesimi gibi Louvain de Almanların Büyük Savaş'ta Fransa'yı işgali sırasında geçeceği yolun üzerinde olma bahtsızlğını yaşıyordu. (...) 25 A ğustos gece yarısı Alman askerleri kütüphaneye girip her tarafa benzin dökmeye başladılar, sabah olduğunda bina bir enkaz halindeydi, koleksiyonu da artık yok olmuştu. Alevler günlerce sürdü (...)”

Margaret MacMillan ${ }^{2}$

\section{Giriş}

Birinci Cihan Harbi, ${ }^{3}$ milyonlarca canlının hayatına mal oldu. İmparatorluklar dağıldı. Dünya haritası büyük oranda yeniden çizildi. İnsanoğlu, kendi tarihinde o zamana kadar şahit olmadığı nispette silahların tahrip gücünü keşfetti. Cephe ile cephe gerisi çizgisinin belirsizleştiği bir savaş oldu. Sivil halk bu savaştan azami derecede etkilendi. Etnik ve dini kaygıların ötesinde farklı parametreler savaşa yön verdi. Ancak savaşın ana nedeni Avrupa kıtasına sığmayan ve daha önce sömürdükleriyle yetinmeyen büyük devletlerin dünya üzerinde yeni paylaşımlar-sömürgeler elde etme mücadelesiydi.

Dört yıldan fazla süren savaş, ağır şatlar taşıyan ateşkeslerle bitirilmesi sağlanmışsa da kurulan yeni düzen bir barış getirmedi. Sadece yeniden bir toparlanma için

1 İ. Hakkı Sunata, İstanbul'da İssgal Yılları, 3. Baskı, İș Bankası Kültür Yay., İstanbul 2009, s. 52.

2 Margaret Macmillan, Barışa Son Veren Savaş, (çev. Belkıs Ç. Dişbudak), Alfa Yay., İstanbul 2014, s. 14-17.

3 Birinci Dünya Savaşı hakkında Türkçe literatür için bakınız: Ömer Turan, “Turkish Historiography of the First Word War", Middle East Critique, Vol. 23, No: 2, 2014, p. 241-257. 
zaman kazandırdı. Birinci Dünya Savaşı'nın en önemli sonucu İkinci Dünya Savaşıdır. Günümüze kadar siyasi, askeri, iktisadi ve içtimai sonuçlarının ve etkilerinin devam ettiği bu büyük savaşın eğitim sistemi üzerindeki etkilerini değerlendirmeye çalışacağız.

Böylesine geniş ve kapsamlı konuyu bir makale sınırları içerisinde ele almak mümkün değildir. Savaşın etkilerini bir cephe ve başkent İstanbul üzerinden analiz edilmesi planlanmıştır. Savaşın doğrudan muhatabı olan yüksek tahsil öğrencileri ve eğitim kurumları en fazla İstanbul'da yoğunlaşmıştır. Yine Çanakkale Cephesi merkeze yakınlığı ve süresi açısından böyle bir analiz için en isabetli örnektir.

Savaşın eğitim ve kurumları üzerinde etkilerini incelediğimiz bu çalışmada İstanbul, yüksek tahsil ve Çanakkale cephesi ile sınırlama yapsak da Birinci Dünya Savaşı kendi içerisinde bir bütündür. Ve savaş dönemi ve öncesi çıkarılan kanunlar genel ve kapsamlıdır. Dolayısıyla konunun incelenmesi esnasında bazı zorluklar yaşanmıştır. Dolayısıyla bazen savaşın tamamıyla ilgili genel yorumlara da yer verilmiştir.

Çanakkale Muharebeleri, Osmanlı son dönem harpleri içerisinde en kapsamlı ve aynı zamanda en şiddetli savaşlardan birisidir. Bu cephe Birinci Dünya Savaşı'nın seyrini değiştirdiği gibi Osmanlı/Türk toplumunun da kaderini derinden etkilemiştir. İtilaf devletlerinin hedefinde İstanbul, devletin merkezi bulunmakta idi. Bütün planlar boğazın geçileceği üzerine yapılmıştı. Ancak Osmanlı ordusunun bu cephede verdiği mücadele tüm tarafları şaşırttı. Kimse bu kadar üstün bir performans beklemiyordu. Türkler bile hayretini gizlememişti. Türk ordusunun verdiği bu ölüm ka$\mathrm{lım/var} \mathrm{olma} \mathrm{mücadelesi} \mathrm{aynı} \mathrm{zamanda} \mathrm{etkileri} \mathrm{uzun} \mathrm{süre} \mathrm{devam} \mathrm{eden} \mathrm{bir} \mathrm{sürecin} \mathrm{de}$ başlangıcı idi.

\section{Seferberliğin Başlaması}

Seferberlik günleri örfi idarenin de geçerli olduğu bir nevi askeri yönetimin hâkim olduğu bir zaman dilimidir. Ülke kaynakları sarf edilirken daima askeriyenin, ordunun ihtiyaçları ilk sırada yer almıştır. Bunun en iyi göstergesi savaş bütçesinin genel bütçeye oranıdır. Savaş yıllarında Meclis-i Vükela'nın kararlarının analitik bir analizi yapıldığında genel itibariyle savaşın idamesi ve savaş nedeniyle ortaya çıkan sorunların çözümüne yönelik olduğu görülmektedir. Ülkenin tüm kaynakları; ordunun ihtiyaçlarını öncelikle ve ehemmiyetle karşılamak için planlanır ve sarf edilirdi Tekâlif-i Harbiye Kanunu zaten bunun en iyi uygulamasıdır. ${ }^{4} \mathrm{Bu}$ kanun askeri otoriteye halkın elindeki her türlü emtiayı \% 60’lara varan oranda el koyma yetkisi vermektedir. Örfi idarenin yetkisi sadece iaşe, seferberlik ve güvenlik ile sınırlı değildi.

Askeri organizasyonun ve ordunun harekât halinde olması için gerekli en önemli unsur, insan gücü ve bu gücün cepheye sevk ve idaresidir. Askeri yönetim sisteminde

4 “Tekâlif-i Harbiye'nin Suret-i Tarhı Hakkında Kanun” için bakınız: Düstur, II, C. 6, s. 1011-1012. 
yer alan menzil teşkilatı, ahz-ı asker şubeleri, merkez kumandanlıkları, iç güvenlikte Jandarma teşkilatı, örfi idare mahkemeleri bu sistemin işlemesi için temel unsurlardır. ${ }^{5}$ Ancak harbiye teşkilatının merkez ve taşra şubelerinde istihdam ettiği ve kullandığı mekânlar noktasında doğrudan askeriye ait olmayan birimlerde en büyük kalemi Maarif Nezareti teşkilatı karşılamıştır. Okullar mimari açıdan ve kamu binaları olmaSı açısından askeri otorite tarafından sıklıkla işgal edilmiştir. Geçici kullanım hakkı alınmıştır. Öncelikle hastane, kumanda merkezi, karargâh merkezi, talimgâh, üsera kampı, darüleytam, mülteci ve muhacirlere sığınak gibi çok fonksiyonlu kullanıma tabi tutulmuştur.

Seferberlik başladığında Dersaadet ahz-ı asker meclislerinin toplantılarını yapmak ve mükelleflerin askerlik işlemlerini takip etmek için elverişli ve korunaklı bina olmadığını ifade eden Harbiye Nazırı Enver Paşa, okullar tatilde iken Fatih Merkez Rüştiyesi, Vefa İdadisi, Koca Mustafa Paşa ve Soğukçeşme Rüştiyelerinden münasip birer dershanenin ahz-1 asker meclislerine tahsis edilmesini rica etmiştir. ${ }^{6} \mathrm{Bu}$ sinıfların askere alma işlemlerinde muayene-i intihaiye (son muayene) bitimine kadar kullanılacağı ifade edilmiştir. Maarif Nezareti de ordunun talebini 1914-1915 eğitim döneminin başlangıcında (Eylül başında) iade edilmek şartıyla kabul etmiş ve okul müdürlerinin bilgilendirilmesi ve gereğinin yapılması için konuyu İstanbul Maarif Müdürlüğüne havale etmiştir. ${ }^{7}$ Ahmet Emin [Yalman] birçok vilayette okulların askeri amaçlarla işgal edildiğini, çünkü buralardaki en geniş ve kullanışlı binaların okullar olduğu belirtmiştir. ${ }^{8}$

\section{Seferberlikte Öğretmenlere ve Vaizlere Düșen Görevler}

Seferberlik ilanından kısa bir süre önce Harbiye Nazırı Enver Paşa tarafından gönderilen bir yazı maarif teşkilatının ülke çapında nasıl seferber edildiğini göstermesi açısından son derece önemlidir. Seferberlik ilan edilmeden önce hazırlıkların yapıldığı görülmektedir. Zaten Balkan Savaşları'ndan sonra 1914 yılı tamamen askeri hazırlıklar ile geçmişti. ${ }^{9}$ Aynı zamanda Balkan bozgununda yaşanan acı tecrübelerin

5 Birinci Dünya Savaşı’nda Osmanlı seferberliği üzerine yapılan kapsamlı ve güncel bir çalışma için bakınız: Mehmet Beşikçi, Birinci Dünya Savaşı’nda Osmanlı Seferberliği, İş Bankası Kültür Yay., İstanbul 2015. Ayrıca, Stanford J. Shaw, Birinci Dünya Savașı’nda Osmanlı İmparatorluğu: Birinci Cilt, Savaşa Giriş, Tercüme: Beyza S. Aydaş, Türk Tarih Kurumu Yay., Ankara 2014, s. 109-308.

6 Enver Paşa imzalı ve 19 Temmuz 1914 tarihli yazı için bakınız: Başbakanlık Osmanlı Arșivi [BOA], Maarif Nezareti, Mektubî Kalemi [MF. MKT]. Dosya No:1199- Gömlek No:61, (1332 Ş 26), lef 1.

7 BOA, MF. MKT. 1199-61, (1332 Ş 26), lef 2.

8 Ahmed Emin, Turkey in the World War, Yale Unv. Press, New Haven, 1930, p. 224.

91913 ve 1914 senelerinde orduda yapılan modernizasyon çalışmaları için bakınız: Edward J. Erickson, Size Ölmeyi Emrediyorum! Birinci Dünya Savaşı’nda Osmanlı Ordusu, 3. Baskı, (çev. M. Tanju Akad), Kitap Yayınevi, İstanbul 2011, s. 17-74. 
tekrar etmemesi için bazı önlemler alınmıştır. Harbiye Nezareti yazışmalarında sık sık Balkan hezimetine atıf yapmaktadır. ${ }^{10}$

28 Temmuz 1914 tarihli yazıda, bütün mekteplerdeki muallimler ve camii ve mescit gibi kutsal mekânlardaki din görevlilerinin halk üzerindeki tesiri ve önemi ifade edildikten sonra öğretmenlerin ve vaizlerin seferberlik için yapmaları gerekenler açıklanmıştır. "İslam'ın ve hükümet-i Osmaniye’nin temin-i bekâ ve selameti" için muallim ve vaiz efendilerin hazırlanan liste çerçevesinde milleti savaşa hazırlık adına teşvik ve yüreklendirmesi talep edilmiştir. ${ }^{11}$

Harplerde maneviyatın önemine değinildikten sonra Müslümanların din, devlet ve vatan uğruna savaşmaları gerektiği, eğer bu duygularla hareket edilmezse mağlubiyetin muhakkak olacağı belirtilmiştir. Eli silah tutan her ferdin "cengâverliğe" hazırlanması gerektiği önemle vurgulanmıştır. Son Balkan Harbi'nde Avrupalı devletlerin Hristiyanlık namına nasıl hareket ettiği ve Balkan devletlerine yaptıkları yardımlar ifade edilmiştir. Vatan, millet duyguları zayıf olan Osmanlı askerleri Balkan Harbi'nde silahını ve cephanesini bırakarak firar etmesi koca Rumeli'nin elden çıkmasına ve İslam'ın her türlü şenaat ve zulümlere maruz kalmasına neden olmuştur. ${ }^{12}$ Balkan Savaşları'nda yaşanan hezimetin nedeni askerin manevi duygularının ve vatan sevgisinin eksik olmasına bağlanmıştır. Harbiye Nazırına göre; orduda itaat ve fedakârlık olmadan muzaffer olmanın imkânı yoktur. Askeri talim ve terbiyede bu duyguların aşılanması hedeflenmektedir. Ancak bunların kısa süreli ve kısıtlı eğitimlerde elde edilmesi mümkün değildir. Onun için bu hasletlerin mekteplerde, evde ve kutsal mekânlarda verilmesi gerekmektedir. Mükellef olan her fert sıra kendisine geldiğinde ve çağrıldığında vatan millet aşkı ve fedakârlık hisleri ile dopdolu olması gerekmektedir. Bu duygular ile yetiştirilen nesiller askerlik için pratik faydası olacak bazı eğitimleri okullarda, derneklerde ve ibadet mahallerinde öğrenmesi, ayrıca halkın ordu için vatan için bazı fedakârlıklar yapması istenmiştir. Enver Paşa tarafından yazının ehemmiyeti hususunda gerekli özenin gösterilmesi birkaç kez vurgulanan ve ilgililere tebliğ edilmesi rica edilen liste şu şekildedir: ${ }^{13}$

- Öncelikle bütün gençler beden terbiyesi ${ }^{14}$ ile yetiştirilip çevik, kuvvetli ve her zorluğu aşacak dirence sahip olması gerekir.

- Ata binmek, at beslemek ve bunların dinen gerekli olduğu ve ehemmiyeti vurgulanmalı ve ecdadın at sevgisi, merakı çocuklara izah edilmelidir.

10 BOA, Dahiliye Nezareti İdari Kısım Evrakı [DH. ID]. 224-3, (1333 S 9).

11 BOA, MF. MKT. 1200-1, (1332 N 7), lef 2.

12 Balkan Savaşları'nda yaşanan felaketler için bakınız: Edward J. Erickson, Büyük Hezimet: Balkan Harpleri'nde Osmanlı Ordusu, (çev. Gül Ç. Güven), İş Bankası Kültür Yay., İstanbul 2013.

13 BOA, MF. MKT. 1200-1, (1332 N 7), lef 1.

14 Yiğit Akın, Gürbüz ve Yavuz Evlatlar: Erken Cumhuriyet’te Beden Terbiyesi ve Spor, İletişim Yay., İstanbul 2005. 
- Kılıç, tüfek, revolver gibi silahların mükemmelen kullanılması ve iyi nişan alınmasının öğretilmesi,

- Yukarıdaki askeri ve bedeni tecrübelerin elde edilmesi için Güç dernekleri$n \mathrm{e}^{15}$ üye olunması ve yeni derneklerin teşkil edilmesi,

- Seferberlikte önemli olan hızlı hareket edip bir an önce hazır olmaktır. Geç kalmanın acı tecrübeleri Balkan harbinde görülmüştür.

- Harp aynı zamanda fedakârlık demektir. Bütün millet canıyla malıyla orduya yardım etmeli bütün halk elinde bulundurduğu öküzünü, atını, arabasını ve bir çuval da olsa zahiresini kanunlar dairesinde ve senet karşıllğında orduya teslim etmesi gerekir.

Görüldüğü gibi seferberliğe hazırlığın önemli hususlarını içeren millet-i müsellaha ruhunu yansitan ve tekâlif-i harbiyenin nüvelerin taşıyan bu maddeler maarif teşkilatı vasıtasıyla tüm ülkeye yayılmış ve öğretmenler, vaizler yoluyla halka anlatılması istenmiştir. Maarif Nezareti ordunun taleplerini içeren bu 6 maddelik listeyi teksir ederek tüm maarif müdürlüklerine ve okullara göndermiștir. ${ }^{16}$ Okul müdürleri de bunları öğretmenlere dağıtmıştır. İlginçtir İstanbul'da Darülmuallimât müdürünün bu listeyi kadın öğretmenlere de dağıttığı görülmektedir. ${ }^{17}$ Muallimler ve din görevlilerinin en ücra yerlere kadar ülkenin her noktasında var olduğunu düşündüğümüzde bu yöndeki faaliyetlerin etkili olacağı ifade edilmelidir. Osmanlı seferberliğinde imkânların da kısıtlı olmasından dolayı sözlü propagandanın azımsanmayacak oranda etkili olduğu ve halkın bu şekilde motive edilmesinde önemli mesafeler kat edildiği bilinmektedir. ${ }^{18}$

\section{Çanakkale Cephesi'nin Açılması Sonrası Yaşananlar}

Çanakkale Muharebelerinin birinci kısmı olan deniz savaşları esnasında başkent İstanbul'da idari ve askeri önemler alınmış ve şehrin savunulması planlanmıştır. Ocak, Şubat ve Mart aylarında devam eden hazırlıklar incelendiğinde şehrin savunulmasının amaçlandığı görülmektedir. Bu tedbirler içerisinde bir takım önemli şahısların ve evrakların taşınması da gündeme gelmiștir. Hazine, kıymetli eşyalar ve mukaddes emanetler Konya'ya nakledilmiştir, hükümet üyelerinin de Eskişehir'e nakledilmesi

15 Cihan Harbi'nde Güç Dernekleri için bakınız: Sanem Y. Ateş, Asker Evlatlar Yetiştirmek: II. Meşrutiyet Dönemi'nde Beden Terbiyesi, Askerî Talim ve Paramiliter Gençlik Örgütleri, İletişim Yay., İstanbul 2012.

16 BOA, MF. MKT. 1200-1, (1332 N 7), lef 3.

17 BOA, MF. MKT. 1200-1, (1332 N 7), lef 9.

18 Seferberlikte sözlü propagandanın önemi için bakınız: Mehmet Beşikçi, Birinci Dünya Savaşıında Osmanlı Seferberliği, s. 89-95. 
planlanmıştır. ${ }^{19}$ İtilaf donanması boğazı geçtiği takdirde acilen devlet adamlarının tahliye edilmesi planı dâhilinde dönemin Maarif Nazırı Ahmet Şükrü Bey ile birlikte hareket edecek olan maarif bürokratlarının isimleri ve adresleri polis müdürlügüne bildirilmiştir. ${ }^{20}$ Acil tahliye esnasında bu şahısların evlerinden alınması ve durumdan haberdar edilmesi istenmiştir.

Yine bu tahliye esnasında ve "fevkalade hal" dolayısılla ve okulların tatil edilmesi durumunda mekteplerde yatılı kalan öğrencilerden velisi veya yakını olmayan kimsesiz çocukların mağdur olmaması ve açlık çekmemesi için bu çocukların bulunduğu kurumların en az bir ay yetecek kadar un, şeker, pirinç, yağ gibi temel gıda malzemelerini stoklaması ve ilgili personelin okulda istihdam edilmesi için yazışmalar yapılmış ve her kurum kaç kişilik yetim barındırmak zorunda olduğunu ve müstahdemlerin listesini bildirmiştir. ${ }^{21}$

Buna göre Çamlıca İnas Numune Mektebi, Darülmuallimîn, Darülmuallimât, İstanbul, Galatasaray, Kadıköy, Nişantaşı, Bezmialem Valide Sultanîleri ve Darüleytam müdürlüğü gerekli hazırlığı yaparak ihtiyaçlarını ve mevcut durumlarını bildirmişlerdir. Mart 1915 tarihi itibariyle yukarıda zikredilen okullarda 740 adet kimsesi olmayan bakıma muhtaç öğrenci bulunmaktadır. 3 Mart 1915 tarihli polis müdürlügüne gönderilen "gizli" yazıda șu ifadelere yer verilir:22

Düşman donanmasının İstanbul'a gelmesi ihtimali üzerine kimsesizlikleri hasebiyle "mekâtib-i leylide ibate ve it'ama mecburiyet hâsll olacağı tahmin olunan kız ve erkek öğrenciler ile müstahdemlerin adedini gösterir cetvel gönderilmiștir. Şehir halkının iașesi ve muhafazası için alınan tedbirler arasinda adı geçen mekteplerin de nazarı dikkate alınmast ve bunları mevkilerine göre tebligat yapilması" istenmektedir. $^{23}$

Alınan tedbirler göstermektedir ki Osmanlı Devleti en zor şartlarda bile teb’asını korumak için gerekli tedbirleri almış ve șehrin savunulması için hazırlıklar yapmıștır. Özellikle kimsesiz çocukların kaderine terkedilmeden onların devam edecek bir şehir savunmasında aç kalmamaları için en az bir ay yetecek gıda depolaması yapılmıștır.

Yine Maarif Nezareti 1914-1915 yeni eğitim döneminin açılış zamanında yatılı okullarda kalan öğrenciler için bazı tedbirlerin alınması için yetkileri uyarmıştır. Bilindiği üzere örfi idare gereği halkın temel ihtiyaçları arasında yer alan ekmek hükümetin kontrolü altında üretim ve dağıtım yapılmaktaydı. Şehir halkının açlık

19 Çanakkale Savaşları esnasında İstanbul'da yaşananlar için bakınız: Mustafa Selçuk, Hedef Şehir İstanbul, Çanakkale Geçildi mi?, Emre Yay., İstanbul 2005, s. 46-61.

20 Maarif Nezareti tarafından Polis Müdüriyet-i Umumiyesi'ne 4 Mart 1915 tarihinde "mahrem" kodlu yazı ile bildirilmiştir. BOA, MF. MKT. 1206-12, (1333 R 10).

21 BOA, MF. MKT. 1206-12, (1333 R 10).

22 BOA, MF. MKT. 1206-12, (1333 R 10).

23 BOA, MF. MKT. 1206-12, (1333 R 10). 
çekmemesi için askeri otorite ile koordineli çalışan Şehremaneti ve Polis müdürlüğü mevcut kaynakları iktisatlı bir şekilde kullanıyordu. Fırınlara verilecek günlük un miktarı belliydi. Ancak halk bazen fırınlarda ekmek bulamadığı gibi yatılı okulların ekmek ihtiyacı da problem olabiliyordu.

İstanbul (Galata'da), Galatasaray (Beyoğlu'nda), Kadıköy (Kadıköy'de), Niaşantaşı (Nişantaşı'nda), Bezmialem Valide (Cağaloğlu'nda) Sultanîlerinde, Çamlıca İnas Sultanîsi'nde (Acıbadem'de), Darülmuallimînde (Kadıköy-Moda), Darülmuallimâtta (Çapa'da) ve Darüleytamlarda (Kadıköy-Moda, Galata'da, Yedikule'de) kayıtlı yatılı öğrencilerin aç kalmaması için 4 Ekim 1915 tarihinde konuyu Harbiye Nezareti'ne bildiren Maarif Nezareti, fırınlara okulların ihtiyacı kadar fazladan un verilmesini talep etmiștir. ${ }^{24}$ Altı gün sonra bu yazıya cevap veren Harbiye Nezareti, Şehremaneti'nin bu konuda gerekli işlemleri yapacağını ifade etmiştir. ${ }^{25} 17$ Ekim'de bu sefer Şehremaneti'ne başvuran Maarif Nezareti okulların isimlerini ve bulundukları mahalleri de liste halinde göndermiş ve ekmek talebini yenilemiştir. ${ }^{26}$ Şehremaneti ise 30 Ekim'de verdiği cevapta Beyoğlu, Kadıköy, Beyazıt, Fatih ve Üsküdar belediye dairelerine gerekli talimatların verildiği "ahalinin isyanına sebep vermemek şartıyla" gerekli yardım ve kolaylığın gösterileceğini hatta ihtiyaç duyulursa zabıtanın da yardımcı olacağını ifade etmiștir. ${ }^{27}$ Okulların bulunduğu belediye daireleri bilgilendirilerek bu okulların ekmek ihtiyacı en yakın mahaldeki fırınlardan temin edilmesi kararlaştırılmıştır. Ancak Maarif Nezareti'nin tüm uyarılarına ve gayretlerine rağmen fırınlara kısıtlı miktarda un verildiği için Nişantaşı Sultanîsi öğrencileri 1 Kasım 1915 gecesi ekmek bulamadıkları için aç kalmışlardır. Nezaret tüm yazışmalara rağmen öğrencilerin aç kalmasını 2 Kasım tarihli yazısı ile Şehremaneti'ne bildirerek Nişantaşı Sultanîsinin bulunduğu bölgedeki Meşrutiyet Mahallesi fırıncısı Remzi Efendi'ye yatılı okulun günlük ekmek ihtiyacı için fazladan her gün bir çuval un verilmesini rica etmiş ve bu aksaklıkların devam etmemesini temenni etmiştir. ${ }^{28}$ Diğer okulların bulunduğu bölgelerdeki fırıncıların listelerinin de gönderileceği ifade edilmiştir. Sene başında gerekli tedbirleri alan ve İstanbul'un savunması konusunda hazırlıklar yapan dönemin idarecilerinden Süleyman Kâni Bey de hatırlarında Üsküdar tarafı için "bugünlerde halkın iaşesi ve asayişin muhafazası en mühim ve mesuliyetli işimiz olacaktı" demektedir. ${ }^{29}$ İdareciler halkın ve öğrencilerin açlık çekmemesi için gerekli tedbirleri alsalar da zaman zaman aksamalar yaşanmaktadır.

24 BOA, MF. MKT. 1212-49, (1333 Za 25), lef 2.

25 BOA, MF. MKT. 1212-49, (1333 Za 25), lef 3.

26 BOA, MF. MKT. 1212-49, (1333 Za 25), lef 4.

27 BOA, MF. MKT. 1212-49, (1333 Za 25), lef 5.

28 BOA, MF. MKT. 1212-49, (1333 Za 25), lef 6.

29 Süleyman Kâni İrtem, Meşrutiyetten Mütarekeye (1909-1918), (haz. O. S. Kocahanoğlu), Temel Yay., İstanbul 2004, s. 614. 
Çanakkale Savaşları devam ederken İtilaf devletlerinin yaptığı uluslararası hukuk ihlalleri yaptığı bilinmektedir. Özellikle Çanakkale şehrinde sivil yerleşim yerlerinin bombalanması, hastanelerin ve yaralı taşıyan gemilerin hedef seçilmesi savaş hukukuna uymayan faaliyetler olarak tarihe geçmiştir. Çanakkale'de ve Marmara denizinde yaşanan hukuk ihlallerine karșı Harbiye ve Hariciye Nezaretlerinin tarafsız devletler nezdinde sayısız uyarı girişimleri bulunmaktadır. ${ }^{30}$ Bu konuda Osmanlı Devleti, İtilaf ve müttefik devletlerce de kabul edilmiş olan 1907 Lahey Antlaşması'na atıf yapmaktadır. Bu antlaşma gereğince tarihi eserler, eğitim, din ve sanat kurumlarının ve sivil yerleşimlerin hedef olarak vurulmaması ve bu gibi binaların tanınması ve tespiti için bir takım işaretler kabul edilmiştir. İstanbul'da deniz harekâtının devam ettiği şubat ayında Maarif Nezareti kendi sorumluluğu altındaki tüm mektep binalarına, Müze-yi Hümayun'a ve tarihi eserlere tedbir amaçlı olarak binaların tanınması için tahta levhaların hazırlanması ve gerektiğinde asılmasını talep etmiştir. Tüm kurum müdürlerine "gayet mahrem ve müsta'cil" koduyla gönderilen yazı üzerine ilgili okul idarecileri şekli tespit edilmiş olan işaretleri hazırladıklarını ifade etmişlerdir. ${ }^{31}$

Yine Maarif Nezareti, 4 Mart 1915 tarihinde düşman donanmasının İstanbul önlerine gelmesi ve şehrin işgale uğraması ihtimaline karşı kendisine bağlı okul, matbaa, müze gibi kültür ve eğitim kurumlarında özellikle okullardaki eşyaların demirbaş listelerinin yedeklenmesini talep etmiştir. Resmi evrakların içinde özellikle diploma ve muhasebe kayıtları gibi önemli belgelerin nasıl muhafazası mümkün ise o şekilde hareket edilmesi ve mümkünse defter ve kayıt evraklarının bir sandık içinde saklanmasını "ehemmiyetle tavsiye" etmiştir. ${ }^{32}$

\section{Okulların Hastane Olarak Tahsis Edilmesi}

Harbiye Nezareti, Osmanlı Devleti’nin silahlı tarafsızlık döneminde tedbir amaçlı bir kısım eğitim kurumlarını hastane olarak belirlemiști, Hilâl-i Ahmer Cemiyetỉ ${ }^{33}$ ve Şehremaneti'nin de yardımları ile seferberlik günlerinde tespit edilen mekânlarda

30 Çanakkale Muharebelerinde İtilaf donanması ve ordularının yaptığı hukuk ihlalleri konusunda şu çalışmalarda detaylı bilgi bulunmaktadır. Osmanlı Belgelerinde Çanakkale Muharebeleri I ve II, TC. Başbakanlık Devlet Arșivleri Gen. Müd., Ankara 2005; Ahmet Tetik-M. Sükrü Güzel, Osmanlılara Karşı İslenen Savaş Suçları (1911-1921), İș Bankası Kültür Yay., İstanbul 2013; Tülay Alim Baran, "Çanakkale Savaşında Hukuk İhlalleri", Atatürk Araştırma Merkezi Dergisi, Sayı: 73, Cilt: 25, Mart 2009; Mesut Erşan, "Çanakkale Muharebelerinde Savaş Hukuku İhlalleri", Atatürk Araştırma Merkezi Dergisi, Sayı: 73, Cilt: 25, Mart 2009, s. 164-179; Cemalettin Taşkıran, "Çanakkale Savaşlarında İtilaf Devletlerinin Hasta ve Yaralılarımıza Saldırıları", Çanakkale Araştırmaları Türk Yıllığı, Sayı: 1, Mart 2003, s. 103-113.

31 BOA, MF. MKT. 1206-12, (1333 R 10).

32 BOA, MF. MKT. 1206-12, (1333 R 10).

33 Cemiyetin savaş yıllarındaki faaliyetleri için bakınız: Mesut Çapa, Kızılay (Hilâl-i Ahmer) Cemiyeti (1915-1925), Ankara 2010; Seçil Akgün-Murat Uluğtekin, Hilâl-i Ahmer'den Kızllay'a, c. I, Ankara 2000; Cemal Sezer, "Birinci Dünya Savaşı'nda Hilâl-i Ahmer Cemiyeti'nin Sağlık Alanındaki Faaliyetleri, History Studies, Volume: 4, Issue: 4, November 2012, s. 373-384. 
hazırlıklara başlanmıştır. İlk etapta İstanbul'da Tıp Fakültesi (700 yatak), Kondüktör mektebi (100 yatak), Darüşşafaka (500 yatak), Darülfünun (Zeynep Hanım Konağı) (500 yatak), Baytar mektebi (250 yatak), İstanbul Sultanîsi (300 yatak) ve Beyoğlu Sultanîsi (500 yatak), Kabataş İdadisi (250 yatak), Kuleli, Jandarma gibi askeri okullar hariç olduğu halde bile savaşın başında İstanbul'da 11 binden fazla yatak kapasiteli hastaneler hazır edilmiștir. ${ }^{34} \mathrm{Bu}$ sayının yarısına yakını okul binalarından karşılanmıștır. Çanakkale'de kara savaşları başladığı andan itibaren İstanbul'a yaralı akını başlamış ve bunların tedavisi için yeni mektepler tahsis edilmiş ve mevcutların da kapasitesi artırılmıştır. İstanbul İnas Sultanîsi gibi kızların devam ettiği okullar da hastane olarak hizmet vermiştir. Gazetelere verilen ilanlarda 1914-1915 eğitim döneminde İstanbul'daki sultanî mekteplerden sadece Mercan, Gelenbevi, Davut Paşa'da eğitime başlanacağı diğerlerinin hastane olarak hizmet vereceği ifade edilmiş, öğrencilerin en yakın sultanîlere devam etmeleri istenmiștir. ${ }^{35}$

Hilâl-i Ahmer'in kontrolünde olan hastanelerin toplam kapasitesi 5500 olmuş ve bu hastanelerde yaklaşık 20 bin yaralı tedavi edilmiştir.$^{36}$ Çanakkale Cephesi'nde muharebenin şiddeti arttıkça ve bölgeden yaralı ve hasta sevkiyatı da artmıștır. 25 Nisan'da başlayan çıkartma harekâtı Türk ordusunda önemli kayıplara neden olmuştu. Çanakkale'deki sahra hastanelerinin yeterli gelmemesi sonucunda yaralılar gemilerle İstanbul'a nakledilmiştir. Bu arada yukarıdaki satırlarda ifade edildiği gibi İtilaf donanmasının boğazı geçme ihtimali karşısında Ocak, Şubat ve Mart aylarında İstanbul'da alınan tedbirler arasında Hilâl-i Ahmer Cemiyeti de sağlık malzemelerini Eskişehir'e ihtiyaten göndermişti. ${ }^{37}$ Kara savaşlarının 18 Mart saldırısından kısa bir süre sonra başlaması İstanbul'daki yetkilileri hazırlıksız yakalamıştı. Yine de kriz iyi yönetilerek yaralılara acil müdahale yapıldığı anlaşılmaktadır. ${ }^{38}$ Kemal Özbay'ın ifadesiyle, ${ }^{39}$ "Hasta ve yaralıların sürekli olarak İstanbul’a tahliyesi karşısında, İstanbul hastaneleri kâmilen dolmuştu. Beliren ihtiyacı gidermek için şehrin muhtelif yerlerinde Ordu ve Kızllay yardımı ile Balkan savaşında olduğu gibi resmi ve özel okul, kurum ve binalar hastane haline sokulmuştu" denilmektedir.

34 Lokman Erdemir, Çanakkale Savaşı: Siyasi, Askeri ve Sosyal Yönleri, Gökkubbe Yay., İstanbul 2009, s. 346-347; Ahmet Esenkaya, "Çanakkale Muharebelerinde Cephede ve Cephe Dışında Sağlık Hizmetleri”, Çanakkale Araştırmaları Türk Yılllı̆ı, Yll: 9, Sayı: 10-11, Bahar-Güz 2011, s. 25-70.

35 İsmail Sabah, "Çanakkale Savaşlarının Eğitim Kurumuna Etkisi (1915-1916)", Çanakkale On Sekiz Mart Üniversitesi, Eğitim Bilimleri Enstitüsü, Yayınlanmamış Yüksek Lisans Tezi, Çanakkale 2013, s. 11.

36 Osmanlı Hilâl-i Ahmer Mecmuası, nr. 5, s. 114; L. Erdemir, "Çanakkale Muharebe Meydanlarından İstanbul Hastanelerine: Sağlık Hizmetleri", s. 100.

37 Osmanlı Hilâl-i Ahmer Cemiyeti 1335 Senesinde Münakıd Hilâl-i Ahmer Meclis-i Umumisi Heyet-i Muhteremesine Takdim Edilen 1330-1334 Senelerine Ait Merkez-i Umumi Raporu, Matbaa-i Orhaniye, İstanbul 1335, s. 9.

38 A. Esenkaya, "Çanakkale Muharebelerinde Cephede ve Cephe Dışında Sağlık Hizmetleri”, s. 49-58.

39 Kemal Özbay, Türk Asker Hekimliği Tarihi ve Asker Hastaneleri, c. 1, İstanbul 1976, s. 233. 
Çanakkale Cephesi'nden İstanbul'a yoğun yaralı nakli Harbiye Nezareti ile Maarif Nezaretini karşı karşıya getirmiştir. Harbiye Nezareti'nin İstanbul Sultanîsini bir gecede boşaltılması için 30 Nisan 1915 tarihli talebi Maarif Nazırı Şükrü Bey'in itirazına neden olmuştur. Çünkü İstanbul Sultanîsi'nde Balkan Savaşlarında şehit olan askerlerin kız çocukları barınmaktadır. Ve sayıları da 200 kadardır. Şükrü Bey, aynı gün acil kayıtlı cevap yazısında kimsesiz yetim çocukların bir gecede nasıl tahliye edileceğini ve nereye yerleştirileceğini sormuştur. Başkumandanlık tarafından gönderilen "memur-ı mahsus"un yani özel temsilcinin "bu yetimleri sokağa mı bırakacak" diyerek tepki göstermiştir. ${ }^{40}$ Şükrü Bey İslam mekteplerinin tahliye ve işgali yerine Beyoğlu'ndaki gayrimüslim ve ecnebi müesselerinin öncelikle işgal edilmesi gerektiğini ifade etmiştir.

Harbiye Nezareti ise Balkan Savaşları esnasında hazırlanan liste üzerinden okulların hastane olarak kullanıldığını ifade etmiş, "yetim kız çocukları için maarif idaresi tarafindan bir konak kiralanabilir/tutulabilir ancak bir bakanlık emri ve isteğiyle oteller ișgal olunamaz fakat okullar tatil edilebilir" diye sert bir cevap vermiștir. Harbiye Nezareti, yine diğer ecnebi okullara da sıra geleceğini ifade etmiş ve "bu gece gelecek yaralıları sokakta mı bırakalım" diye sormuștur. ${ }^{41}$ Ahmet Şükrü Bey ise, aynı gün verdiği ikinci cevabi yazısında aslında savaşı komuta eden karargâh-1 umuminin uygulamalarını eleștirmeye devam etmiş ve plansız, danışılmadan iş yapıldığını vurgulamıştır. Şükrü Bey, öncelikle birkaç kolordunun askerini barındıracak kadar İstanbul'da boş hane olduğu halde yaralıların sokakta kalma ihtimalinin ifade edilmesine şaşırdığını ve utandığını ifade etmiştir. Otellerin işgal olunamamasının hikmetini anlayamadığını belirterek İstanbul Sultanîsi'nin acil olarak tahliye edilemeyeceğini yinelemiştir. ${ }^{42}$ Burada Ahmet Şükrü Bey'in eleştirileri gerçeği yansıtmaktadır. Çünkü -her ne kadar basında çok yer almasa da- Çanakkale bombardımanı devam ettiği günlerde birçok kamu görevlisi ailesini Anadolu içlerine göndermişti. Yine İstanbul'da en az 6 kolorduya sahip iki ordunun bulunduğunu ve İstanbul'da yeterince askeri tesis, kışla olduğu bilinmektedir. Ancak Harbiye Nezareti’nin asıl isteği hem İstanbul Limanı'na yakın hem de sağlık hizmetlerine uygun ve tıbbi malzemenin bulunduğu mekânlar öncelikli olarak işgal edilmektedir. ${ }^{43}$

İstanbul'da Şehremaneti'nin desteği, kadın cemiyetlerinin girişimi ve halkın ileri gelenlerinin gayretleri ile muhtelif kapasitedeki birçok resmi ve hususi okul, kurum ve binalar hastane olarak kullanılmaya başlanmıștır.44 1916 ortalarına kadar İstanbul'daki hastanelerde yüz bine yakın hasta ve yaralı tedavi edilmiştir.

40 ATASE, K. 2418, D. 25, F. 3-9. (Aktaran: İ. Sabah, a.g.t, s. 13).

41 ATASE, K. 2418, D. 25, F. 3-9a. (Aktaran: İ. Sabah, a.g.t, s. 13).

42 ATASE, K. 2418, D. 25, F. 3-7. (Aktaran: İ. Sabah, a.g.t, s. 13).

43 İstanbul'da işgal edilen tüm mekânların listesi için bakınız: Esenkaya, "Çanakkale Muharebelerinde Cephede ve Cephe Dişında Sağlık Hizmetleri", s. 49-58.

44 Erdemir, “Çanakkale Muharebe Meydanlarından İstanbul Hastanelerine: Sağlık Hizmetleri”, s. 101. 
İdarecisi, öğretmeni, öğrencisi, mezunu, memuru ve okul binalarıyla önemli bir miktarda ordunun yükünü hafifleten maarif teşkilatı; cephe gerisinde ve cephede savaşın idamesi için bütün imkânlarını seferber etmiştir. Ancak ilkokul öğretmenlerinin bile askere alınması, yine öğretmen yetiştiren kurumların mezun verememe ihtimali karşısında Maarif Nezareti eğitimin tamamen kesilmemesi için Harbiye Nezareti'ne gerekli uyarıları yapmıştır. Yukarıdaki satırlarda ifade edildiği gibi kamu binalarının işgali yerine Rum ve Ermenilere ait müesseselerin işgal edilmesi tavsiye etmiştir.

Harbiye Nezareti ve onun teşvik ve yetkilendirmesiyle Hilâl-i Ahmer Cemiyeti'nin ısrarlı istekleri ve savaşın şiddetlenmesi dolayısıyla söz verilen zamanda tahliye edilemeyen binalar karşında Maarif Nezareti yine Harbiye Nezareti'ne dünyadaki uygulamalardan da örnek vererek maarif imkânlarının sınırsız bir şekilde kullanılmasına itiraz etmiştir.

Ahmet Şükrü imzalı 30 Ağustos 1915 tarihli bir yazıda, okulların açılma zamanı gelmesine rağmen henüz tahliye edilmeyen, eğitime başlamaları birinci derecede ihtiyaç duyulan Galatasaray, Kadıköy ve Bezm-i Âlem Sultanîleri ile Darülfünun binasının (Zeynep Hanım Konağı) acilen tahliye edilmesi taleplerine olumlu bir cevap alınamadığı belirtilmiștir. Maarif Nazırı savaşan devletlerin hiçbirisinde resmi eğitim kurumlarının işgal edilmediği, askeri sağllk hizmetleri için hususi mekteplerin/binaların işgal edildiğini ifade etmiştir. Avrupa'da eğitimin devam etmesi için bütün kurumların gerekli hassasiyeti ve fedakârlığı gösterdiği belirtilmiștir. Avrupa'daki incelemelerde bulunan ve son olarak da İtalya'ya uğrayan Maarif Nezareti müşaviri de benzer izlenimlerini aktarmıştır.

Ahmet Şükrü Bey; zaten Balkan Savaşları ve Cihan Harbi nedeniyle üç seneden beri eğitimin düzenli olarak yapılamadığı gibi bu savaşlarda şehit olan askerlerin kimsesiz çocukları da yine eğitim kurumlarında istihdam ve barındırıldıklarını ifade etmiştir. Ahmet Şükrü Bey İtilaf kuvvetleri safında harbe iştirak eden İtalyan müesseselerinin değerlendirilmesini istemiştir. Harbiye Nezareti ise beş gün sonra verdiği cevapta Kadıköy Sultanîsinin tahliye edileceğini, diğerlerinin ise bir müddet daha hastane olarak işgalinin devam edeceğini ve bazı ek tedbirlerin alınması gerektiği tavsiye etmiştir. ${ }^{45}$

Maarif Nazırının savaşlardan dolayı "üç senedir düzenli eğitim yapamadlk" açıklamasını en iyi şekilde eğitim istatistikleri ve kurumların mezuniyet rakamları doğrulamaktadır. Maalesef savaş zamanında istatistik de tutulamamış arşivde münferit bazı cetvellere rastlanmaktadır.

Maarif Nezareti bir yandan yaşanan olağanüstü durum ve bir yandan da askeriyenin baskısı ile çıkan harp kanunları neticesinde eğitimin birçok kurumda durma

45 Sabah, a.g.t., s. 27-28. 
seviyesine gelmesi karşısında ne yapacağını bilemez hale gelmiştir. Aşağıdaki satırlarda maarif bürokratlarının yaşadığı duygu yoğunluğu açık bir şekilde görülmektedir.

1914-1915 eğitim sezonunun bitmesine sadece 25 gün kalmışken, mekteplerin tatil edilmesi, "ümid-i istikbali millet olan yüzlerce evlâd-ı vatanın, hayat-ı tahsillerinde bir devre-i tevakkuf" olacağı açık ise de "devlet-i ebed-i Osmaniyenin temîn- $i$ bekâ ve selameti" için girmiş olduğu "şu muharebe-i azîmede" hilafet merkezinin muhafazası için bütün gayretlerini ortaya koyan askerlerin tedavisi için yer tahsisi de yerine getirilmesi gereken önemli bir vazife olduğu belirtilmektedir.

Yüzlerce öğrencinin tahsillerinin kesintiye uğraması iyi bir intiba bırakmayacağı ifade edilirken bir yandan da devletin bekası ve İstanbul muhafazası için her şeylerini feda eden gazilerin tedavisi için gerekli mekânların hazırlanması için sorumluluğu altındaki mektep binalarının hastane haline getirilmesine izin vermiștir.

Burada son olarak işgal edilen yabancı eğitim kurumlarından kısaca bahsetmek gerekir. İstanbul bașta olmak üzere Osmanlı coğrafyasında faaliyette olan yabancı okulların çoğu savaş başladığında faaliyetlerini durdurmak zorunda kalmıştır. Osmanlı Devleti, bu eğitim kurumlarına el koymuş ve çeşitli şekillerde değerlendirmiştir. Birçoğu yine hastane ve eğitim amaçlı kullanılmıştır. İstanbul'da yoğun bir şeklide faaliyette bulunan Fransız, İngiliz, Rus ve daha sonraları İtalyan mekteplerine Meclis-i Vükela kararılya el konulmuş, bina içerisindeki malzemelerin demirbaş listesi tutularak kayıt altına alınmıştır. ${ }^{46} \mathrm{Bu}$ şekilde İstanbul'da ellisi Fransız, altısı İngiliz, üçü Rus ve sekizi İtalyan olmak üzere toplam 67 eğitim kurumuna el konulmuştur. Bunların bir kısmı hususi mekteplere tahsis edilmiştir. ${ }^{47}$ Kadıköy, Galata, Bebek, Yedikule ve Küçükçekmece'de bulunan Fransız, İtalyan ve İngilizlere ait mekteplerin bir kısmı da boşaltılarak Darüleytam'a tahsis edilmiştir. ${ }^{48} \mathrm{Bu}$ okulların idareci ve personeli, öğretmenleri memleketlerine iade edilmiştir. ${ }^{49}$ Düşman devlet ve tebaasına ait okullar hakkında yapılan işlemlerle ilgili arşivde müstakil bir çalışma yapmaya yetecek kadar belge bulunmaktadır. Maarif Nazırı Ahmet Şükrü Bey’in ısrarla gündeme getirdiği yabancı okulların işgali meselesi savaş boyunca etraflıca uygulanmış bir politikadır. $\mathrm{Bu}$ uygulamaların da etkisiyle İtilaf Devletleri Cihan Harbi sona erdikten sonra işgal döneminde ilk iş olarak bu kurumların iadesini ve tekrar faaliyetlerine başlamasını sağlamış, ayrıca misliyle Türk kurumlarını işgal etmiştir.

$46 \quad B O A, M F . M K T .1203-1,(1333 \mathrm{M}$ 1).

47 BOA, MF. MKT. 1202-75, (1332 Z 30).

48 BOA, MF. MKT. 1203-30, (1333 M 14).

49 BOA, MF. MKT. 1203-37, (1333 M 17). Bu uygulamadan istisna tutulan ve görevlerine devam ettirilen bazı Fransız muallimlerin de olduğu görülmektedir. Galatasaray Sultanîsindeki uygulamalar için bakınız: BOA, MF. ALY. 80-1, (1333 B 6). 


\section{Mezun ve Öğrencilerin Silâhaltına Alınması}

Cihan Harbi boyunca üç milyona yakın nüfus silâhaltına alındı. Mükellefiyet-i Askeriye Kanunu'na ${ }^{50}$ muhatap olan en önemli kesim ise yaşları 20 ile 27 arası olan genç nüfus idi. Oranlara bakıldığında seferberliğin asıl yükünü gençlerin çektiği görülmektedir. Her ne kadar askerlik kanunu 45 yaş daha sonra 50 ve üstünü kapsasa da en fazla silâhaltına alınan kesim gençler idi. Osmanlı devletinde okuma yazma oranının düşük olduğu genel kanaat olarak ifade edilse de mevcut okuyan ve mezun olan öğrenciler içerisinde askerlik çağında olanların neredeyse tamamı silâhaltına alınmıştır. Müslüman nüfustan askerlik şartlarını taşıyanların büyük bir çoğunluğu askerlik çağrısına cevap vererek bu vazifeye katılmışlardır.

Henüz savaş başlamadan önce yenilenen mükellefiyet-i askeriye kanununa göre hizmet-i maksure olarak adlandırılan kısa dönem askerliği içerisinde yüksekokul, üniversite mezun ve müdavimleri, lise mezunları ve son iki sınıf müdavimleri bu kanuna göre askere çağrılmıştır. Burada kanunların tanımladığı kapsam oldukça geniştir. Tüm resmi, hususi ve yabancı mekâtib-i âliye, Darülfünun, Sultanîler, yedi senelik idadîler ve 6. sene imtihanını veren talebe-i ulûm yani medrese öğrencileri. Tahsil-i âli diye tanımlanan yükseköğrenim mezunları ve hangi sınıfta olduğu fark etmeksizin mevcut devam eden öğrencilerin tamamı bu çağrıya cevap vermek zorundadır. Sultanî ve idadîlerin mezunları istisnasız askere alınırken okula devam edenlerden son iki sene yani 11 ve 12 sınıflar askere çağrılmıştır. Daha sonra ihtiyaç artıkça 10. s1nıflar da mükellef tutulmuştur. Burada tabi gayrimüslimlerin açtığı hususi mektepler ve yabancı devlet tebaasına ait veya doğrudan ecnebi devletlerin açtı̆̆ı okulların öğrencileri de bu mükellefiyete tabii iseler de oralardan fazla katılım olmadığı bilinmektedir. Savaşın yükü daha çok Müslüman ve Türk tebaanın omuzlarına yüklenmiştir. Kısa dönem askerlik süresi bir yıl olarak planlansa da seferberlik ve savaş boyunca askerlerin terhisi geciktirilmiş hatta savaş bitene kadar terhis edilmeyeceklerine dair karar alınmıştır. ${ }^{51}$

İstanbul'da yoğunlaşan Darülmuallimîn-i Âliye, Orman Mektebi, Halkalı Ziraat Mektebi, Ticaret Mektebi, Mühendis Mektebi, Kondüktör Mektebi gibi yüksekokulların 1913-1914 eğitim istatistiğine göre sayıları; 16'sı Maarif Nezareti'ne, 6’sı diğer nezaretlere bağlı olmak üzere toplam 22'dir. Bu okullarda toplam öğrenci sayısı 5522 'dir ve 1913-1914 eğitim döneminde mezun olanların sayısı ise 627 kişidir. $^{52} \mathrm{Se}$ kiz tanesi İstanbul'da faaliyet gösteren Sultanîlerin ülke genelinde toplam sayısı 36'dır ve bu okullara 9134 Müslüman öğrenci kayıtlıdır. Bu öğrencilerden 136'sı diploma

5012 Mayıs 1914 tarihli "Mükellefiyet-i Askeriye Kanun-1 Muvakkatı” için bakınız: Düstur, II. Tertip, c. 6, s. 662-704.

51 BOA, Meclis-i Vükela Mazbataları [MV]. 1916-116, (1333 R 09).

52 Mehmet Ö. Alkan, Tanzimat'tan Cumhuriyet’e Modernleşme Sürecinde Eğitim İstatistikleri, Ankara 2000, s. 272. 
almıştır. $^{53}$ İstanbul'da mezun olanların sayısı ise 33'dür. İstanbul'da faaliyet gösteren sekiz Sultanî, 600 kadar öğrencisini başta Çanakkale olmak üzere çeşitli cephelere göndermiştir. Ülke genelinde idadîlerin sayısı 59'dur. Darülfünun'da ise 1913-1914 eğitim dönemi sayılar şu şekildedir: ${ }^{4}$

\begin{tabular}{|l|c|c|c|}
\hline Fakülte & Toplam öğrenci & 1913 mezunu & 1914 mezunu \\
\hline İlahiyat & 318 & 54 & 33 \\
\hline Edebiyat & 201 & 30 & 8 \\
\hline Fen & 99 & 4 & 4 \\
\hline Hukuk & 2201 & 506 & 189 \\
\hline Tip sivil & 592 & 76 & 84 \\
\hline Tip askeri & 306 & 22 & 31 \\
\hline Eczacı M. & 129 & 11 & 11 \\
\hline Dişçi M. & 54 & 28 & 48 \\
\hline & 3900 & 731 & 408 \\
\hline
\end{tabular}

Darülfünun ile birlikte tüm yüksekokullarda yaklaşık olarak 10 bin kadar öğrenci kayıtlı olduğu anlaşılmaktadır. Bunların tamamı potansiyel olarak seferberlik muhatabıdır. Sultanîler ise II. Meşrutiyetle birlikte yaygınlaşmaya başladığı için henüz yeni mezun vermeye başlamışlardır. Dolayısıyla bu okullarda son iki sınıfa (ilerleyen tarihlerde 10. sınıflar da) kayıtlı öğrenci sayıları net olarak bilinmemektedir. Ancak mezun sayıları son derece kısıtlıdır. Bir de idadî ve sultanî mezunları zaten büyük oranda yüksekokullara veya yurt dışına gitmektedir. Osman Kafadar ve Ahmet Esenkaya tarafından askerî okullar, meslekî teknik eğitim, taşra medreselerinden derlenen verilere göre yüksekokullarla birlikte 45 bin civarında bir öğrenci sayısına ulaşılmış ve bunların en az yarıya yakını silâhaltına alındığı belirtilmiştir. ${ }^{55}$ Savaşa katılan diğer ülkelerde durum farklı değildir. Öğrenciler, gönüllü veya zorunlu statüde askere alınmıştır. ${ }^{56}$

2 Ağustos 1914'te ilan edilen seferberlik ${ }^{57}$ gereği kanunun kapsamı biraz daha genişletilerek 1887 ile 1894 tarihleri arasında doğan sekiz tertip tahsilli gençlik silâhaltına alınmıştır. İlk palanda 20 ile 27 yaş arası eğitim görmüş kişiler askere çağ-

53 Alkan, a.g.e., s. 226.

54 Alkan, a.g.e., s. 269.

55 Osman Kafadar-Ahmet Esenkaya, “Çanakkale Savaşlarında Kaybedilen Eğitim Görmüș Nesiller Üzerine Düşünceler ve Öneriler”, Çanakkale Araştırmaları Türk Yıllı̆̆ı, Sayı: 2, Mart 2004, s. 153-154.

56 İngiltere'de devlet okullarına devam eden öğrencilerin Birinci Dünya Savaşı'ndaki rolü için bakınız: Steve Hurts, The Public Schools Battalion in the Great War, Pen \& Sword Books, South Yorkshire 2007; Donald Hankey, A Student in Arms, New York 1917.

57 BOA, Hariciye Nezareti Siyasi Kısım Evrakı [HR. SYS]. 2097-1_8, lef 28-29; BEO, 4303-322677; MV. 236-17; “Seferberlik”, Tanin, 3 Ağustos 1914. 
rılmıştır. ${ }^{58}$ Çanakkale Muharebeleri'nin devam ettiği günlerde Rumî 1311 (1895) doğumluların muayene süreleri erkene alınarak biran önce silâhaltına alma yetkisi Harbiye Nezareti’ne verilmiștir. ${ }^{59} 23$ Ağustos 1915’te Rumî 1312 (1896) doğumlular da silah başına çağrılmıştır. ${ }^{60}$ Cephelerde artan zayiatlar karşısında bir ay sonra (23 Eylül 1915'te) Rumî 1313 (1897) doğumluların da celbine karar verilmiștir. ${ }^{61}$ Son iki tertip 19 ve 18 yaşlarındaki fertleri kapsamaktadır. Bu yaş grubu doğrudan idadî ve sultanî öğrencilerini kapsamaktadır. Burada ifade edilen tahsil-i âli mezunu, müdavimi öğrenciler ile sultanî, idadî mezunları ve okulların son iki sene müdavimleri ile medrese talebelerinden şartları taşıyan bütün öğrenciler ilgili kanunlara göre ordunun ihtiyacı olan genç zabit yetiştirme politikası gereği belli bir program dâhilinde talim verilerek kıtalara ihtiyat zabit namzedi veya ihtiyat küçük zabit namzedi olarak tayin edilmişlerdir. ${ }^{62}$ Orduda yedek subay statüsünde görev yapan bu öğrenciler üstlerinin takdir ve tayinleri neticesinde takım ve bölüm komutanları vazifesini icra etmişlerdir. 27 yaş üstü tahsilli gençler ise yedek subay olarak kabul edilmeyip doğrudan er statüsünde değerlendirilmiştir.

Şimdi öğrenciler ile ilgili bu genel bilgiler verildikten sonra öncelikle Darülfünun olmak üzere buradaki öğrencilerin durumu hakkında kaynakların elverdiği ölçüde bazı tespitlerde bulunulabiliriz.

\section{Darülfünun}

İttihatçılar Osmanlı toplumunda yapmayı planladıkları yenileşme hareketlerine eğitim kurumlarını da dâhil etmişlerdir. II. Meşrutiyetten itibaren toplumu yönlendirecek bütün kurumlar bu gözle elden geçirilmiş ve Türk modernleşmesine öncü olacak "yeni" neslin yetiştirilmesine hız verilmiştir. Maarifte yapılan reform hareketleri içerisinde Darülfünun'un ayrı bir yeri vardır. Yenileşme hareketleri savaş döneminde hız kesmeden devam etmiştir. Savaş bazı modernleşme hareketlerini hızlandırırken bazılarını da yok etmiştir. Darülfünun bunun en güzel örneğini sunmaktadır. Bir yandan öğrenci yokluğu yüzünden eğitim faaliyetleri durma seviyesine gelirken bir yandan da Darülfünun bünyesinde dil, tarih, eski eserler, kadınların eğitimi, yükseköğretimde özerklik gibi çok önemli girişimler yapılmıștır. O günlerin canlı şahidi ve aynı zamanda üniversite hocası olan Ahmet Emin [Yalman] "Turkey in the World War" isimli eserinde bu hususları ayrıntılı olarak anlatmaktadır. ${ }^{63}$

58 BOA, DH. ID 37-206 lef 36.

59 BOA, Dosya Usulü Iradeler [İ. DUİT]. 76-12.

60 BOA, Dâhiliye Nezareti İdare-i Umumiye, [DH. İUM] E-30-75 lef 16.

61 BOA, DH. IUUM E-30-75 lef 12.

62 Mehmet Beşikçi, “İhtiyat Zabiti’nden Yedek Subay’a: Osmanlı'dan Cumhuriyet'e Bir Zorunlu Askerlik Kategorisi Olarak Yedek Subaylık ve Yedek Subaylar 1891-1930 ”, Tarih ve Toplum Yeni Yaklaşımlar, Sayı: 13, Güz 2011, s. 45-89.

Ahmed Emin, Turkey in the World War, Yale Unv. Press, New Haven, 1930, p. 224-230. 
Birinci Dünya Savaşı’nın öncesinde ve savaş yıllarında Darülfünun teşkilatında önemli değişikler yapılmıştır. Kurulduğu tarihten itibaren uzun yıllar "şube" olarak adlandırılan üniversitenin birimlerine 1913'ten itibaren artık "fakülte" denmeye başlamıştır. II. Abdülhamid zamanından beri Darülfünun'un bir şubesi olan Ulum-1 Şeriye kısmı kapatılmış, Darülfünun'da ders gören Ulum-1 Şeriye öğrencileri Islah-1 Medârisîn Nizamnamesi ${ }^{64}$ hükümlerine göre yeni açılan Darülhilafetil Âliye medreselerinin yüksek kısmına nakil edilmiștir. ${ }^{65}$ Bu uygulama 1924 senesine kadar devam etmiştir. Bu dönemde İlahiyat Şubesi'nin tam olarak ne zaman kapandığına dair bir bilgiyi Tedrisat-1 Âliye Dairesi'nin Darülfünun'a gönderdiği kadro cetvellerinden tespit edebilmekteyiz. 14 Ekim 1915 tarihinden itibaren geçerli olacak yeni teşkilat gereği İlahiyat Fakültesi'nin kadrosu gösterilmemiş ve şöyle bir açlklama düşülmüştür: “Darülfünun Hukuk, Fünun, Edebiyat ve Lisan Şubelerinin bu kere tanzim olunan kadroları 1 Teşrin-i evvel 1331 [14 Ekim 1915]'den muteber olmak üzere leffen taraf-ı valalarına tisyâr kılındı. Bunların tedkikinden anlaşılacağı veçhile Darü'l-Hilafeti'l Âliye medresesinin küşadı hasebiyle vücuduna lüzum kalmayan İlahiyat Şubesi lağv edildiğinden mezkûr șube müdavimlerinin Darülhilafe Medresesine devamları muktezi bulunmuş ve keyfiyet Meşihat'ül Aliye’ye arz edilmiştir." Bu açıklamadan İlahiyat Şubesi'nin 1915-1916 eğitim yılı başında yani en geç 14 Ekim 1915 tarihinden önce kapatıldığı anlaşılmaktadır. ${ }^{66}$

Edebiyat Fakültesi yönetiminde bir Lisan Fakültesi'nin faaliyete geçmesi de doğrudan doğruya savaş koşullarının ortaya çıkardığı bir husustur. Seferberlik gereği sınıfların boşaldığı Müslüman öğrencilerden sağlı problemi olmayanların neredeyse tamamı askere gittiği için fakülteler öğrencisiz kalmıștır. Aynı zamanda II. Meşrutiyetten itibaren sayıları belirgin bir şekilde artan gayrimüslim ve yabancı öğrenciler bu fakültenin müdavimleri olmuştur. Çünkü bu öğrenciler çeşitli vesileler ile veya bedel-i nakdî ödeyerek askerlik yükümlülüğünden kurtulmuștur. 1910 yllında açılan Elsine Şubesi ${ }^{67} 1915-1916$ ders yılı itibari ile fakülteye dönüștürülmüş ve ders programındaki yabancı dil ve öğretim üyesi sayısı artırılmıştır. Örneğin Çince, İtalyanca,

64 Düstur, II. Tertip, c. 6, s.1325-1330; Zeki S. Zengin, Medreseden Darülfünun'a Türkiye’de Yüksek Din Eğitimi, Adana 2009, s. 77-78.

65 Darülhilafe Medreseleri hakkında ayrıntılı bilgi için bkz, Hamit Er, Medreseden Mektebe Geçiş Sürecinde Darülhilafe Medreseleri, İstanbul 2003, s. 21-113.

66 BOA, Maarif Nezareti Tedrisat-ı Âliye Dairesi Evrakı [MF. ALY]. 83-68, (1333 Z 5); ayrıca șubenin 1915 tarihinde kapandığına dair (talebe künye defterlerinden tespit edilen) bir bilgi için bkz, Zeki S. Zengin, Medreseden Darülfünun’a Türkiye'de Yüksek Din Eğitimi, s.77; 1924-1925 yllına ait Talebe Rehberinde İlahiyat Fakültesi'nin tanıtıldığı bölümde “İlahiyat Fakültesi'nin Tarihçesi” bașlıklı yazıda "1331-1915 senesinde medreselerin yeni bir șekle ifrağı ve birçok dersler ilave edilince hâsıl olan istiğnâya binaen Darülfünun Ulûm-ı Diniye Şubesi ilga ve talebesi bilahare Sahn namı alan Darülhilafe Medresesi'nin kısmı Âliyesine devredilmiştir" denilerek şubenin 1915 yılında kapatıldığı vurgulanmıștır. Bkz, T.C. İstanbul Darülfünun Talebe Rehberi, 1340-1341, Yeni Matbaa, İstanbul 1340, s. 104.

67 BOA, MF. ALY. 20- 85 (1328 N 13). 
Urduca, Rumca, Ermenice, Eski Yunanca ve Latince gibi yeni lisanlar eklenmiştir. ${ }^{68}$ Devam zorunluluğu olmayan ve üç seviyede dil eğitimi verilen fakültenin kadrosunu yine Edebiyat Fakültesi öğretim üyeleri oluşturmaktaydı. Bu fakülte ilk açıldığı dönemde öğretim süresi beş yıl olarak düşünülmüştür. Ancak Mütareke dönemi şartlarının getirdiği sıkıntılar ve kadro dışı bırakılan öğretim üyeleri yüzünden Lisan Fakültesi daha mezun veremeden 1919 yılında kapatılmak zorunda kalmıştır. Bu fakültenin kapsamı küçültülerek onun yerine Lisan Mektebi kurulmuş, yüksekokul sevisindeki bu kurumun da ömrü uzun sürmemiştir. Daha dar kapsamlı bir programın uygulanması Edebiyat Fakültesi'ne devredilmiştir.

Zeynep Hanım Konağı olarak bilinen ve II. Meşrutiyetten itibaren Darülfunan'a tahsis edilen konak, daha önce Balkan Savaşları'nda hastane olarak kullanılmıştı. ${ }^{69}$ Çanakkale Savaşlarının devam ettiği günlerde, İstanbul'daki I. Kolordu'nun emri altında ve Hilâl-i Ahmer'in kontrolünde bulunan Darülfünun binası için mevcut 15 müstahdemin geceleri de dâhil olmak üzere hastane hizmetlerinde istihdam edilmesi hastane ser tabipliği tarafından teklif edilmiş ${ }^{70}$ ancak Darülfünun yönetimi 19141915 senesi imtihanları yaklaşmakta olduğundan ve zaten hizmetlilerin geç vakitlere kadar binada çalıştıklarından bahisle sadece yedisinin hastane işleri ile meşgul olmasına izin vermiştir. ${ }^{71}$

Zeynep Hanım Konağı'nın hastane olarak kullanıldığı dönemde binanın pencerelerinden kırk tanesi kırılmıştır. Meydana gelen zararların Harbiye Nezareti'nden tahsil etmek isteyen Darülfünun yönetimi gerekli girişimleri yapmıştır. ${ }^{72}$ Yaralıların tedavisi için kullanılan bina kapalı kaldığı dönemde üniversitede eğitim aksamıştır. Binanın tadilatı yetişmemesinden dolayı 1915-1916 eğitim öğretim yılında derslere Ekim ayının sonlarında ancak başlanmıştır. ${ }^{73}$

\section{Tıp Fakültesi}

Haydarpaşa'da faaliyet gösteren Tıp Fakültesi Darülfünun'un fakülteleri arasında yer alan askeri ve sivil olmak üzere iki çeşit öğrenci mezun eden bir kurumdu. Aynı şekilde Kadırga'da faaliyet gösteren Eczacı ve Dişçi mektepleri de Tıp Fakültesi'nin

68 Nitekim Meclis-i Mebusan'da "Darülfünun'da Almanca'dan başka yabancı dil okutulmuyor, Arabî Farisî lisanlarına önem verilmiyor." eleştirilerine 10 Şubat 1916 tarihli bütçe görüşmelerinin yapıldığı toplantıda Maarif Nazırı A. Şükrü Bey cevap vermiştir: Darülfünun'da Arabî ve Farisî dersleri yanında Urduca, Hintçe hatta Çincenin bile okutulduğunu belirtmiștir. Bkz, Meclis-i Mebusan Zabıt Ceridesi (Bundan sonra MMZC şeklinde kısaltılacaktır.), Devre: 3, İçtima Senesi: 2, c. 1, 28 Kanun-ı sani 1331, Ankara 1991, s. 540. 
yönetimi altında ayrı bir müdür tarafından idare edilmekteydi. Şüphesiz Cihan Harbi'nden en fazla etkilen kurum Tip Fakültesi ve personeliydi. Aynı şekilde öğrenciler de orduda, hastanelerde ve sıhhiye müfettişliklerinde çeşitli rütbelerde sıhhi personel olarak istihdam edilmişlerdi. Fakültenin askeri kısmı zaten ordunun tabip subay ve diğer sağlık ihtiyaçlarını karşılamak üzere istihdam edilmiştir. Fakülte öğretim kadrosunda askeri hekimler ve tabip subaylar da görev almaktaydı.

Seferberlik ilanını müteakip Tıp Fakültesi ihtiyat hastanesi olarak hazırlanmıştı. ${ }^{74}$ İlk planda kapasitesi 700 yatak olarak tespit edilmiștir. ${ }^{75}$ Hastanede çoğu Balkan Savaşı gazilerinden olan 20 kadar hasta ve fakültenin hizmetleri ile ilgilenen 160 kadar hasta bakıcı ve hademe bulunmaktadır. ${ }^{76}$ İlerleyen günlerde hastanenin yatak kapasitesi artırılmıștır.

Savaş başladığında mevcut öğrencilerden son sınıfta olanlar zabit vekili, dördüncü ve üçüncü sınıf öğrencileri başçavuş muavini, ikinci ve birinci sınıflar çavuş rütbesi ile zabit namzedi (subay adayı) olarak istihdam edildiler. Bunlar içerisinde askeri öğrenciler muvazzaf, diğerleri ihtiyat olarak görevlendirildiler. ${ }^{77}$ Savaş esnasında gösterecekleri başarıya göre ilgili kanunlar mucibince rütbe almışlardır. Savaşın başlamasıyla tıbbiyeli öğrenciler, asistan, muallim ve diğer kadrolardaki hocalarıyla birlikte askere alınmış ve çeşitli cephelerde sıhhi hizmetlerde ve hastanelerde istihdam edilmişlerdir. Tıp Fakültesi’nde personel ve öğrencilerin silâhaltına alınması 19141915 eğitim öğretim döneminde faaliyete ara vermek zorunda kalmıștır. ${ }^{78} \mathrm{Bu}$ arada 1914-1915 eğitim öğretim döneminde muhtemelen seferberlik muafiyetlerinden faydalanan veya henüz yaşı tutmayan bazı gayrimüslim öğrencilerin mezun olduğu da anlaşılmaktadır. ${ }^{79}$ Savaşta artan sıhhi personel ihtiyacını karşılamak için fakültede eğitime tekrar başlamak bir zorunluluk idi. Bu durumun farkında olan idareciler eksikler olsa da 1915-1916 eğitim döneminde eğitime tekrar başlamıştır. Tıp Fakültesi Reisinin 5 Ekim 1915 tarihinde Maarif Nezareti'ne gönderdiği bir yazıda bu durum net olarak ifade edilmektedir. "Bu sene müsaade edilirse Tip Fakültesi tedrisatına birinci ve ikinci sinıflarda düzenli olarak daha yukarı sinıflar için ise kısmen başlanacă̆ı" ifade edilmektedir. ${ }^{80}$ Yine Hilâl-i Ahmer Cemiyeti ile yapılan yazışmalarda ise fakültenin Teşrin-i evvel [Ekim] başında eğitime başlanacağı ifade edilmiştir. ${ }^{81} \mathrm{Bu}$ planlamadan da anlaşıldığı üzere fakülte yönetimi eksikler olmak ile birlikte tıp eği-

74 A. Süheyl Ünver, Birinci Cihan Harbinde Tip Fakültesi, İstanbul 1952, s. 3.

75 Lokman Erdemir, Çanakkale Savaşı, s. 346-347.

76 BOA, MF. MKT. 1201-8, (1332 L 14).

77 Kemal Özbay, Türk Asker Hekimliği Tarihi ve Asker Hastaneleri, c. 2, İstanbul 1976, s. 121.

78 BOA, MF. MKT. 1201-8, (1332 L 14).

79 İsmail Sabah, a.g.t., s. 72.

80 BOA, MF. ALY. 83-35.

81 Kızılay Arşivinden elde edilen bir belge için bakınız: İsmail Sabah, a.g.t., s. 73-74. 
timine başlamak istediğini bildirmektedir. Dolayısıyla Tıp Fakültesi'nde eğitime 1916 Ekiminde başlandığı bilgisi doğru değildir. Aynı şekilde fakültenin savaş boyunca hiç mezun vermediğine dair iddialar belgelere dayanmamaktadır. Yazının devamında öğrencilerin maişet problemi yaşadıkları ve zor durumda oldukları için bu öğrencileri teşvik etmek üzere Haydarpaşa civarında yabancı vatandaşlar tarafından terk edilen hanelerin birisinde ikamet etmelerine müsaade edilmesi talep edilmektedir. ${ }^{82}$ Fakülte aynı zamanda hastane olarak da hizmet verdiği için kalacak yer problemi vardı.

Tıp Fakültesi'ndeki zorlu eğitim süresi altı seneden dört seneye düşürülmüş ancak yine de öğrenciler zaman zaman aç kalma tehlikesi ile karşı karşıya kalmışlardır. Kemal Özbay'ın anlatımıyla; 83

"memleketin iktisadi durumu bozulmuş, açlık ve sefalet her gün biraz daha artmıştır. Okul müdürlüleri yokluk içinde yürütülmesine çalıştıkları bu kurumun bu ıstıraptan kurtarılması için ellerinden geleni esirgememiş bir şeyler yapmaya çalışmışlardı. (...) Öğretim hayatı ıstırap, yiyecek önemli bir problem olmuştu. Yemekler kandil yağları ile pişirilmiş ekmekler süpürge tohumu karışımından yapılmıştı. Ağır tıp tahsilini dört yılda bitirmek zorunluluğunda birakılan ve başlıca gıdasını bu ekmekten bekleyen öğrenciler açlıktan Kadıköy, Acıbadem taraflarındaki köşklerin bahçelerinde bekçilerle kavga ederek sebze ve meyve toplamak zorunda kalmışlardı. Noksan gıda yüzünden bir yılda 20'ye yakın öğrenci vereme yakalanmıştı. (...) Savaş sonlarına doğru Çanakkale'den elde edilen ganimet mallardan depolarda bulundurulan konservelerden bir kısmı okullara dă̆ıtılınca, yiyecek işi biraz ferahliğa kavuşmuştu."

Seferberlik günlerinde silâhaltına alınan Tıp Fakültesi et tedarikçisi Lütfi Efendi'nin koyunlarına da ordu tarafından el konulmuş bu durum hastane haline getirilen binada mevcut hastalar için 46 kilo kadar ete ihtiyaç olduğu için el konulan koyunların iadesi Harbiye Nezareti'nden talep edilmiştir. ${ }^{84}$

Sivil öğretim üyelerinin birçoğu silâhaltına alınmıştı. 1915 ortalarında fakülteden gönderilen bir çizelgede 29 yaş üstü ve bedel-i nakdî harici çeşitli nedenlerle silâhaltına alınmaktan istisna tutulan sadece 16 öğretim elemanı bulunmakta ve bunların da beş tanesi muvazzaf subay kadrosundadır. ${ }^{85}$ Tıp Fakültesi kadrosu diğer

\footnotetext{
82 BOA, MF. ALY. 83-35.

83 Kemal Özbay, Türk Asker Hekimliği Tarihi ve Asker Hastaneleri, c. 2, s. 122.

84 “Çok acil” kodlu ve 15 Ağustos 1914 tarihli Maarif Nezareti’nin yazısı için bakınız: BOA, MF. MKT. 1200-27, (1332 N 23).

85 Tıp Fakültesi Reisliği tarafından hazırlanan ve seferberlikten istisna tutulan öğretim elemanlarının isimleri için bakınız: BOA, MF. ALY. 80-32.
} 
fakültelerden fazladır ${ }^{86}$ ancak orduda görevlendirilenlerin ${ }^{87}$ sayısı o kadar fazla ki fakülte meclisi reisliği için yapılan oylamada yeterli çoğunluk sağlanamadığı için seçim yapılamamış ve fakültenin vekâleten idaresi kararlaştırılmıștır. ${ }^{88}$

\section{Hukuk Fakültesi}

Hukuk Fakültesi II. Meşrutiyetten sonra en fazla öğrenciye sahip ve en fazla ilgi gören fakülte idi. Savaşın başında fakülteye kayıtlı yaklaşık iki binin üzerinde öğrenci bulunmaktadır. ${ }^{89}$ Savaş yıllarında Fakülte Reisliği görevini ifa eden hukukçu Ahmet Selahattin Bey, kendi fakültesinde askere gitmek için 1650 gence vesika verdiğini ifade etmektedir. Bu öğrencilerden üç yüz kadarının döndüğünü bir o kadarının da esir düştüğünü geri kalan binden fazla Hukuk öğrencisinin de cephelerde şehit olduğunu belirtmiştir. $^{90}$

Yine Erzurum bölgesinde görevli bir polis memurunun aynı zamanda Hukuk 3. sınıf öğrencisi olan Nami Efendi'nin Eylül imtihanlarının yapılıp yapılmayacağını sorduğu dilekçesine 1914-1915 eğitim öğretim döneminde tedrisat icra edilmediği için imtihanların da yapılmasına imkân olmadığı yönünde cevap verilmiștir. ${ }^{91}$ Bu yazışmalardan anlaşıldığ üzere Hukuk Fakültesi'nde 1914-1915 dönemi savaş nedeni ile eğitime devam edilememiştir.

Seferberlik emri karşısında bazı öğretim elemanları ve memurlar mazeret bildirmişlerdir. Hukuk Fakültesi öğretim üyelerinden ticaret-i berriye muallimi Ali Kemal Bey (d. 1295-Selanik), iktisat ve maliye muallimi Fazıl Bey (d. 1302-Selanik) ve fakülte kâtiplerinden Abdülvahap Efendi (d. 1301-Gostivar), muhacir olduklarını belirterek askerliklerini tecil ettirmişlerdir. ${ }^{92}$

\section{Fen Fakültesi}

Edebiyat Fakültesi ile birlikte Zeynep Hanım konağında faaliyet gösteren Fünun Fakültesi Tabilyat ve Riyaziyat şeklinde iki farklı diploma vermektedir. 1915-1916 eğitim öğretim yılından itibaren yeni teșkilat gereği bölüm sayısı artmıştır. Yeni teşki-

86 Savaş başlangıcında fakülte kadrosunda 90, Eczacılıkta 15, Dişçilikte 4 olmak üzere toplam 109 öğretim elemanı bulunmaktaydı, M. Alkan, a.g.e., s. 270.

87 Neşet Ömer, Derviş ve Asaf Paşalar gibi meşhur tıpçıların orduda görevlendirilmesi hakkındaki izin yazıları için bakınız: $B O A, M F . A L Y .78-52$.

88 BOA, MF. ALY. 77-116.

89 1913-1914 istatistiğine göre Hukuk Fakültesi'nde 1644 Müslüman ve 557 diğerleri olmak üzere toplam 2201 öğrenci kayıtlıdır. M. Alkan, a.g.e., s. 269.

90 Tarkk Zafer Tunaya, Türkiye’de Siyasi Partiler, c. 3, İletişim Yay., İstanbul 2000, s. 261.

91 BOA, MF. ALY. 82-53, lef 2.

92 BOA, MF. ALY. 79-40, lef 1. 
lat gereği Darülmualimîn-i Âliye'nin yüksek kısım öğrencileri derslerini Darülfünun Fen ve Edebiyat Fakültelerinde görmekte idiler. Edebiyat Fakültesi ile birlikte ortak pedagojik derslerin de yer aldığı bir program takip edilmekteydi. Fen ve Edebiyat Fakültesi mezunları genel itibariyle muallimlik mesleğinde istihdam edilmektedirler. Taşra merkez okullarında azami derecede öğretmene ihtiyaç olduğu için bu öğrencilerin tahsillerini tamamlamaları teșvik edilmiștir. Darülmaullimînde yatılı olarak kalan ve seferberlik muafiyetinden yararlanan öğrencilerin ağırlıkta olduğu bir grup dersleri takip etme imkânı bulmuştur. Sayıları son derece sınırlı olan bu öğrenciler genelde Rum, Ermeni cemaatindendir ve bu öğrenciler eğitimlerini tamamlamayı başarmışlardır.

\section{Edebiyat Fakültesi}

Ziya Gökalp, Köprülüzade Fuad, Faik Sabri, İsmail Hakkı, Necib Asım, Babanzade Ahmed, Akçuraoğlu Yusuf, Ahmed Ağayef, Şemseddin gibi önemli bilim adamlarını kadrosunda barındıran Edebiyat Fakültesi savaş yıllarında Laleli'de bulunan Zeynep Hanım Konağında eğitim öğretim faaliyetlerini devam ettirmiştir. Bu dönemde fakülte müdürlüğü görevinde Mahmud Zarif Bey bulunmaktadır.93

Edebiyat Fakültesi Meclisi zabıt ceridelerinde aslında savaşın etkisini net olarak görebilmekteyiz. 1914 ve 1915 yıllarına ait Edebiyat Fakültesi Meclis-i Müderrisîn toplantılarının zabıtları kaybolmuş ve kayda geçirilememiştir. Bu yıllara ait bazı toplantıların özetleri verilmiş, bazıları ise hiç yoktur. Örneğin 21 Şubat 1331 [5 Mart 1916] ile 9 Kanun-1 sani 1332 [22 Ocak 1917] tarihleri arasındaki on aylık dönemin kayıtları bulunmamaktadır. 1332-1333 (1916-1917) ders yılı zabıtlarının bulunduğu sayfanın başına eklenen "ihtar"da bu kayıplara dair bir açıllama getirilmiş; iki yıllık sürede zabıtlar zamanında deftere kayıt edilemediği ve bazı müsveddelerin kayıp olduğu belirtilmiştir. ${ }^{94}$

Ekonomik sıkıntılar yayın faaliyetlerini de kesintiye uğratmıștır; mürekkep yokluğundan dolayı ${ }^{95}$ Edebiyat Fakültesi Mecmuası ve kâğıt yetersizliğinden dolay ${ }^{96}$ İçtimaiyat Mecmuası bir süre basılamamıştır. Aynı şekilde Matbaa-ı Amire'de basılan ders formalarında gecikmeler yaşanmıştır. ${ }^{97}$ Öğretim üyelerinin en temel ihtiyaçları olan kahve ve su ücretleri bile idare tarafından karşılanamamış ve hocaların maaş-

93 Darülfünun Edebiyat Fakültesi hakkında geniş bilgi için bakınız: Mustafa Selçuk, İstanbul Darülfünunu Edebiyat Fakültesi (1900-1933), Atam Yay., Ankara 2012.

94 IDF. EF. MMZD-II, Z.N.1, 9 Kanun-1 sani 1332.

95 İstanbul Darülfünun Edebiyat Fakültesi Meclis-i Müderrisîn Zabit Defteri, 2. defter [İDF. EF. MMZDII], Z.N.5, 6 Şubat 1332.

96 IDF. EF. MMZD-II, Z.N.8, 28 Şubat 1334-1918.

97 IDF. EF. MMZD-II, Z.N.9, 22 Nisan 1334-1918. 
larından otuzar kuruş kesinti yapılmıştır. ${ }^{98}$ Soğuk kış günlerinde öğretim üyelerine ve fakülte personeline odun kömür yardımı yapılmış, darülemesailerin ısıtılmasında tasarruf yapılması tavsiye edilmiştir. ${ }^{99}$ Avrupa'dan ve diğer ülkelerden sipariş edilen ders araç ve gereçlerinde gecikmeler yaşanmıştır.

Edebiyat Fakültesinde öğrenciler gibi idareciler, memurlar ${ }^{100}$ ve öğretim elemanları da silâhaltına alınmıştır. Öğretim üyelerinin birçoğu askerlik problemi yaşamış ve cepheye çağrılmıştır. Bazı öğretim üyeleri çeşitli mazeretlerle durumunu tecil ettirmiştir. ${ }^{101}$

Tarih-i İslam muallimi Halim Sabit Efendi (d. 1299), muhacir olduğu için muaf tutulmuştur. Arapça muallimi Bağdatlı Fehmi Bey (d. 1288), yaş haddinden tecil edilmiştir. ${ }^{102}$ Arapça muallimi Şevket Bey (d. 1288), maluliyetine binaen Aksaray askerlik şubesinden sağlık raporu almıştır. Tarih-i umumi muallimi Ahmed Ağayef (d. 1285-Kafkasya) muhacir olduğu için muaf tutulmuştur. Tarih-i Asrı Hazır muallimi Yusuf Akçura (d. 1299) seferberlik müddetince ihtiyat erkânı harp yüzbaşılığı rütbesi bulunmakta, "irade-yi seniyye" ile muaf tutulmuştur. Coğrafya müderrisi Faik Sabri Bey (d. 1298), Temmuz 1330-1914 celp döneminde Üsküdar Ahz-1 Asker Şubesi sağllk kurulundan rapor alarak askerliğini tecil ettirmiştir. Türk Edebiyatı müderrisi Fuad Bey (d. 1306) bedel-i nakdî ödeyerek silâhaltına alınmaktan kurtulmuştur. ${ }^{103}$ Savaşın ilerleyen yıllarında Harbiye Nezareti öğretim üyelerini takip etmeye devam etmiş ve daima askerlik mevzusunu gündeme getirmiştir. 1917 ortalarında Edebiyat Fakültesi mensubu 6 öğretim elemanının durumu Darülfünun'dan sorulmuştur. Bunlardan Tarih muallimi M. Arif Bey'in Tarih-i Osmanî Encümeni vazifesinden dolayı istisna edildiği, Farsça muallimi Abdulkadir Nuri Efendi'nin ise elinde "ihraç" tezkiresi bulunduğu belirtilmiş ve bu şahısların öğretim üyesi oldukları için fakülte idaresi tarafından "tecil edilmesi lazım geleceği" ifade edilmiștir. ${ }^{104}$

Maarif Nezareti'nin eğitimin aksamaması için bazı öğretim elemanları hakkında tecil ve tehir talepleri Harbiye Nezareti tarafindan "ahvali hazıranın arz ettiği ehemmiyet hasebiyle caiz görülmemiş" gerekçesi sunularak ret edilmiş ve öğretim elemanlarının askerlik durumları ile ilgili sık sık çizelgeler hazırlanmış ve silâhaltına alınmama nedenleri izah edilmiștir. ${ }^{105}$

Müttefikimiz Almanya'da da öğretim üyelerinin silâhaltına alındığı ve birçoğunun da savaş meydanlarında zayii olduğu Maarif Nezareti'nde müşavir olarak istih-

98 IDF. EF. MMZD-II, Z.N.2, 16 Kanun-1 sani 1332.

99 BOA, MF. ALY. 114-18, (1336 Ca 28).

100 BOA, MF. ALY. 80-47, (1333 В 22).

101 BOA, MF. ALY. 79-40, (1333 C 20), lef 3.

102 BOA, MF. MKT. 1224-71, (1331 C 10); MF. MKT. 1225-35, (1331 C 26).

103 BOA, MF. MKT. 1235-75, (1336 Za 24).

104 BOA, MF. MKT. 1228-119, (1335 Za 9).

105 BOA, MF. MKT. 1222-13, (1335 Ra 17), lef 4. 
dam edilen Prof. Dr. Franz Schmidt tarafından ifade edilmektedir:106 "Hali hazırda Almanya harp ile meşgul bulunduğundan profesörlerin intihabı hususunda bazı müşkülata tesadüf olunmuştur. Zira birçok genç Alman âlimleri harp meydanlarında bulunmaktadır. Bir takımları dahi yaralanmış veyahut telef olmuştur."

\section{Edebiyat Fakültesi'nde Kayıtlı Öğrencilerin Durumu}

Savaş yıllarında Edebiyat Fakültesi, mali problemleri öğretim üyelerinin ve idari personelin fedakârlığı ile aşmaya çalışmıştır. Ancak aşılamayan problem; sınıflardaki öğrencilerin giderek azalmasıdır. Bundan dolayı bir süre fakültede öğretim üyelerinden daha az sayıda öğrenci grubu ile eğitimine devam edilmiştir. Öğrenci yokluğundan dolayı yeni açılan kürsüler boș kalmış, aynı şekilde Almanya'dan getirilen müderrislerden faydalanılamamıştır.

Savaş başladıktan sonra yüksekokullardaki tüm Müslüman öğrenciler cepheye koşmuşlardır. Geriye sadece, gayrimüslim, yabancı ve askerliğe elverişsiz öğrenciler kalmıştır. Darülfünun'a giriş şartlarında yapılan hafifletmelere rağmen Darülmaullimîn talebesi dışında fakülteye neredeyse hiç öğrenci gelmemiştir. Felsefe Bölümü öğretim üyelerinden M. Emin [Erişirgil] bu dönemde Felsefe Şubesi'nde sadece iki öğrencinin bulunduğunu belirtmektedir. ${ }^{107}$

Burada dönemin kayıtlarına sahip ve inceleme imkânı bulduğumuz Edebiyat Fakültesi arşivinde bulunan talebe kayıt ve künye defterlerinden savaşın fakülteye ve dolayısıyla eğitim sistemine etkilerini açık bir şekilde tespit edebilmekteyiz. Maalesef benzeri kayıtlar diğer fakülte ve okullarda ya mevcut değil ya da araştırıcıya açık olmadığından karşılaştırma imkânı bulunmamaktadır.

Kayıtlı öğrenci sayılarının giderek azalmasını künye defterlerinden takip edebilmekteyiz. Savaş dönemi mezunları arasında yer alması gereken 1911, 1912, 1913, 1914 ve 1915 girişlilerin künye bilgileri; yaşanan sıkıntıyı en iyi şekilde ifade etmektedir. Rumî 1327 [1911], 1328 [1912] ve 1329 [1913] yılları arasında fakülteye kayıt olanların künyesinin tutulduğu Darülfünun Edebiyat Şubesi Künye Defterinde; ${ }^{108}$ öğrencilere 1'den 74'e kadar numara verilmiş ve fakülteye 74 öğrenci kayıt edilmiştir. $\mathrm{Bu}$ öğrencilerden sadece 14 tanesi eğitimlerini tamamlayabilmiştir. Üstelik 14 kişinin

106 BOA, MF.ALY. 84-46, (1333).

107 M. Emin Erişirgil, “Ziya Gökalp”, Ülkü, Sayı: 55, İstanbul, Kanun-1 sani 1944, s. 2.

108 Darülfünun Edebiyat Şubesi Künye Defteri (1329-1330) isimli defter; İ.Ü. Edebiyat Fakültesi Arşivinde yer alan künye defterleri içerisinde en erken tarihli bilgileri içermektedir. Edebiyat Şubesi için bu defterden daha eskisi bulunmamaktadır. Örneğin II. Abdülhamid ve II. Meşrutiyet devrinin ilk yıllarına ait verileri içeren defterler yoktur. 1-74 arası kayıtların yer aldığı ve öğrencilere "cedit" [yeni] numaralar yanında atîk [eski] numaraların da belirtilmesinin sebebi çalışmamızın II. Bölümünde bahsettiğimiz 1911 yılında Darülfünun'da çıkan yangında bazı evrakların zarar görmüş olmasıdır. Bkz, İ.Ü. Edebiyat Fakültesi Arşivi: Darülfünun Edebiyat Şubesi Künye Defteri (1329-1330), nr. 1-8/4 (15). 
dört tanesi de Mütareke döneminde mezun olmuştur. Geri kalan atmış kişinin fakülte ile ilişkisi kesilmiştir. Bu öğrencilerin büyük bir kısmının cepheden dönemediği anlaşılmaktadır. Yine 1912, 1913, 1914, 1915 ve daha sonraki yıllarda fakülteye kayıt olmuş öğrencilerin künyelerinin yer aldığ Darülfünun Ulum-ı Edebiye Şubesi Künye Defteri-II isimli ikinci defterdeki öğrencilerin durumu daha kötüdür. Çünkü 75-94 arasında kayıtlı 20 öğrenciden; sadece bir kişi 1919 yılında mezun olabilmiştir. Diğer 19 öğrencinin devamsızlıktan dolayı kayıtları silinmiştir. Savaş dönemi kayıt olan öğrencilerin de yer aldığı bu defterde 75-166 arası numaraların tahsis edildiği toplam 74 öğrenci künyesi yer almaktadır. 74 kişiden yukarıda bahsettiğimiz bir öğrenci de dâhil olmak üzere ancak 20 kişi Mütareke ve Cumhuriyet dönemlerinde mezun olmayı başarabilmiştir. Geri kalan öğrencilerin devamsızlıktan dolayı kayıtları silinmiștir. ${ }^{109}$

Bu iki künye defterindeki veriler kısmen eksiktir. Çünkü kayıtlı öğrenci sayılarının daha fazla olduğu istatistik cetvellerinden anlaşılmaktadır. 1913 yılında tüm sınıflarda toplam 266 öğrenci, 1914 yılında ise mezun olanlar çıkartılıp ve yeni gelenler eklendiğinde mevcudun 201 olduğu görülmektedir. Yeni kayıtlar ile birlikte her yıl ortalama iki yüz kadar öğrenci olması gerekirken bu rakam savaşın yeni cephelere yayılması ile bir anda tek haneli rakamlara kadar gerilemiştir. ${ }^{110}$

Savaşın son senesi olan 1918'e gelindiğinde Türk Lisaniyatı, Elsine-yi Samiye Lisaniyatı ve Tarih-i Kadim, Avrupa Tarihi, Arabî, Farisî, Fransızca, Almanca ve İngilizce zümreleri kayıtlı öğrenci olmadığından dolayı açılamamıştır. Sadece Darülmuallimîn talebesine yönelik Fransızca ve Almanca dersleri devam ettirilmiştir. ${ }^{111}$ Savaş yıllarında fakültenin öğretim elemanı sayısı yabancı müderrisler ve muavinlerle birlikte altmışı geçmiştir. Bu sayı Darülfünun tarihi boyunca fakültenin en geniş akademik kadroya ulaştığı yıllardır. ${ }^{112}$ Ancak ne yazık ki savaş boyunca fakültenin toplam kayıtlı asli öğrenci ve mezun sayıları bu rakama ulaşamamıştır. Tarihte örneğine az rastlana-

109 Darülfünun Ulum-ı Edebiye Şubesi Künye Defteri-II isimli defterde 1911-1919 arası kayıtlar yer almaktadır. 130 numaradan sonra sadece çift numaralar erkek öğrencilere tahsis edilmiş, 131, 133, 135 gibi tek numaralar ise farklı bir defterde kız öğrencilere verilmiştir. Bu yüzden 75-166 arası 91 numara yer alması gerekirken toplam sayı yine 74'dür. Bkz, I. Ü. Edebiyat Fakültesi Arşivi: Darülfünun Ulum-ı Edebiye Şubesi Künye Defteri - II (1329-1330), nr. 1-8/5 (16).

110 1913-1914 yıllarında Edebiyat Şubesi'ne kayıtlı öğrencilerin hangi millet ve mezhepten olduklarına dair ayrıntılı bilgi için bkz, Mehmet Ö. Alkan, Tanzimat'tan Cumhuriyet'e Modernleşme Sürecinde Ĕ̈itim İstatistikleri, s. 269.

111 Maarif Nezareti her yarıyıl sonunda öğrenci yoklama listelerini fakültelerden talep etmektedir. Edebiyat Fakültesi müdüriyeti yukarıda adı geçen zümrelerin hiç öğrencisi olmadığını ve diğer zümreler için de derslerin yeni teşkilat gereğince darülmesailerde müderrislerin kontrolünde yapıldığını, dolayısıyla ayrıca yoklamaya gerek görülmediğini bildirmiştir. 26 Mart 1334-1918 tarihli müdüriyet-i umumiyenin nezarete yazısı için bkz, BOA, MF. $A L Y$. 115-83, (1336 B 20), lef 2-3.

112 BOA, MF. ALY. 84-54, (1333) lef 1; MF. ALY. 134-126 (1337 Ş 16); MF. ALY. 172-11, (1341 S 12), lef 14; MF. ALY. 106-35, (1335 L 19). Ayrıca karşılaştırma için bkz, Cengiz Orhonlu, "Edebiyat Fakültesi'nin Kuruluşu ve Gelişmesi (1901-1933) Hakkında Bazı Düşünceler”, Cumhuriyetin 50. Yılına Armağan, İstanbul 1973, s. 64. 
cak şekilde bu dönemde; bir eğitim kurumunda akademik personel sayısı öğrencilerden daha fazla sayıya sahip olmuştur.

Öğrenci yokluğu özellikle Alman müderrisleri konferans vermek, kitap yazmak gibi farklı alanlarda yoğunlaşmalarını sağlamıştır. Sınıflarda bulunan az sayıdaki öğrencileri bir dershanede toplayıp tüm birinci, ikinci ve üçüncü sınıflara ortak dersler yapan Alman müderrisler arta kalan zamanlarda darülmesailerinde vakit geçirmişler. Mecliste uzun süren ilmî-teorik tartışmalara zemin oluşturan Alman müderrisler, toplantılara da eksiksiz tam kadro katılmayı ihmal etmemişlerdir. ${ }^{113}$

\section{Ermeni Öğrencilerin Durumu}

Çanakkale Muharebelerinin devam ettiği aylar aynı zamanda hükümetin Ermenilere karşı bazı önlemler aldığı ve Ermeni vatandaşlarını yerlerinden göçe zorladığı zaman dilimidir. ${ }^{114} 1915$ yılı içerisinde faaliyetleri artarak devam eden Ermenilere karşı bir dizi kararlar alınmış ve uygulanmıştır. Devlet idaresinde görevli memurlar da bu kararlardan etkilenmiştir.

Dâhiliye Nazırı Talat Bey, 29 Nisan 1915 tarihli bir yazı ile Ermeni komitelerinin uzun bir süreden beri hükümete karşı aldıkları vaziyet ve Doğu Anadolu'da çıkarttıkları ihtilalden ve isyanlardan bahsederek Ermeni memurlara karşı devletin beslediği iyi duygulara rağmen bu memurların çoğunun "hüsnü vazifeden ziyade azim-i milliye ile hareket eden komite mensubu olduklarını" belirtmiş ve yaşanan acı tecrübelerin de dikkate alınarak Maarif Nezareti bünyesinde görevli bulunan bütün Ermeni memurlar hakkında amirlerinden de görüş alınarak görevden uzaklaştırılması gerekenlerin tespit edilerek gereğinin yapılmasını istemiştir. ${ }^{115}$

Dâhiliye Nezareti'nin “mahrem" kodlu yazısı üzerine 1 Mayıs 1915 tarihinde şifre ile Maarif Nezareti tüm vilayetlere bir genelge göndermiş ve "Memurîn-i maarif meyanında Ermeni var ise bunların ahvâl-i hususiye ve efkârı siyasilerine nazaran devam-ı memuriyetlerinin caiz olup olmayacağı hakkında" maarif müdürlüklerinden görüş istenmiştir. ${ }^{116}$

113 Dönemin Meclis-i Müderrisîn reisi Halid Ziya, müstehzi bir edayla onların "kemal-i sadakatle” meclise katıldıklarını ifade etmiştir: "Alman müderrisler, başka yapılacak bir işleri olmadığından meclis müzakerelerinde daima kemal-i sadakatle hazır bulunurlardı. Riyaset mevkiinin sağ tarafında bir yarım halka teşkil ederler ve susarlardı.” Bkz, H. Ziya Uşaklıgil, Saray ve Ötesi, (Haz. Özmel Akın) İstanbul 2003, s. 725.

114 1915 Ermeni olayları hakkında geniş bilgi için bakınız: Bülent Bakar, Ermeni Tehciri, Atam Yay., Ankara 2009; Kemal Çiçek, Ermenilerin Zorunlu Göçü (1915-1917), TTK Yay., Ankara 2005; Recep Karacakaya, Türk Kamuoyu ve Ermeni Meselesi (1908-1923),Toplumsal Dönüşüm Yay., İstanbul 2005; Yusuf Halaçoğlu, Ermeni Tehciri, BKY Yay., İstanbul 2004.

115 BOA, MF. MKT. 1208-38, (1333 C 16), lef 1.

116 BOA, MF. MKT. 1208-38, (1333 C 16), lef 2. 
Ermeni memurların maarif idarelerinden ve Ermeni muallimlerin mekteplerden uzaklaştırıldığına dair bilgiler mevcuttur. Burada bu konu ile bağlantılı olarak devletin iç güvenlik birimlerinin okullardaki öğrencileri de takip ettikleri görülmektedir. Darülmuallimîn-i Âliye son sınıf öğrencisi olup eğitimlerini Darülfünun Fen ve Edebiyat Fakültelerinde gören ve Darülmuallimînde yatılı kalan öğrenciler ile ilgili detaylı raporların tutulduğu anlaşılmaktadır.

Dâhiliye Nezareti Emniyeti Umumiye Müdür-i Umumisi İsmail Canbolat Bey tarafından bizzat Maarif Nazırı Ahmed Şükrü Bey’in şahsına özel gönderilen “mahrem" yazıda Edebiyat ve Tabiıyat üçüncü sınıfta kayıtlı sekiz talebe hakkında önemli bir kaynaktan ve "cidden calib-i dikkat" bazı "ihbar" notları paylaşılmış ve nazır bey efendiden gereğinin yapılması talep edilmiștir. Öğrenciler hakkında bazıları "dediko$d u$ " cinsinden bilgiler şu şekildedir:

Son sınıf talebesinden Harputlu Hamparsum Efendi hafta içi izinli çıtığı zamanlarda Ermeni komitecilerinin ileri gelenleriyle gizlice görüştüğü ve mektebe geldiği zaman da Ermeni talebeyi başına toplayarak onlara gizli ve şifreli bir takım beyanlarda bulunduğu, tutuklanan bir Ermeni'ye yapılanın zalimane olduğunu savaşın başından beri İtilaf devletlerinin bu savaşı kazanacağını açıkça ifade etmekten çekinmemiștir. Yavuz savaş gemisinin Karadeniz'de battığını söylemiştir.

Tabilyat şubesi talebesinden Erzurumlu Yaplak (?) Efendi'nin ateşli bir Türk düşmanı olduğu ve bu ırki düşmanlığını her fırsattan dile getirmekten çekinmediği belirtilmiş. Öğrenci donanma için yardım toplandığı esnada "bizim için faydası olmayan, işimize gelmeyen yerlere nasıl para verelim" demiștir.

Edebiyat şubesinden Haçinli Kevork Efendi'nin hükümetin ordusu, idaresi ve eğitim kurumları gibi Türk ve İslam milletine ait ne varsa hepsinin bozuk ve çirkin olduğunu ifade etmiş, hükümetin Ermenileri yok etmeye çalıştı̆̆ını, Ermeniler ile Türklerin barışamayacağını çünkü iki millet arasında kan davası olduğunu ifade etmiş ve hayatındaki en büyük gayesinin babasının intikamını almak olduğu belirtmiştir.

Edebiyat şubesinden Vanlı Ohannes Efendi'nin mevcutlar içerisinde daha yaşlı olduğu, mektebe yeni başlayan her Ermeni'yi tanısın tanımasın yanına alarak önce onlara güven telkin edip sonra fikirlerini aşıladığı ifade edilmektedir.

Edebiyat şubesinden Vanlı Aram Efendi'nin her Cumartesi mektebe gelir gelmez Ermeni arkadaşlarını bir kenara toplayarak onlara gizlice bir şeyler söylediği ve bir defasında mektepte bulunma gayesinin Ermeniliğin kurutuluşu olduğunu ifade etmiştir.

Tabilyat şubesinden Vanlı Zaru (?) Efendi'nin çeşitli dillere aşina olduğu ve aynı zamanda orta öğretimi Rusça gördüğü ve Rus üniversitesinden mezun olduğu yabancı memleketlerle irtibatlı olduğu, mektepteki iki Çerkez talebenin milliyetçilik 
duygularını tahrik ederek Türklük aleyhine kışkırttığı görülmektedir. Rus lisanına vakıf olması kendisinin Rus menfaatlerine hizmet ettiği anlaşılmaktadır. Edebiyat şubesinden Muşlu Yervant Efendi, Sultan Osman zırhlısının satın alındığı sırada " $b u$ parasızlıkzamanında 3 milyon lira ile gemi almak bilmem hangi akla sığar" demiştir.

Raporun sonunda bu öğrencilerin ahval ve hareketleri cidden şüphe çekici bulunmuş ve öğrencilerin tahkik edilmesi istenmiştir. Ahmed Şükrü Bey, kendi yönetimi altında yüzlerce okul içerisinde bir okul hakkında kendisine iletilen bu istihbarat bilgilerini, mutlaka adı geçen kurum idarecileri ile paylaşmıştır. Burada öğrenciler hakkında derlenen bilgi notlarının birçoğunu kısmen sadeleştirerek verdim. Bu ifadelerle güvenlik kaygısının son derece yüksek olduğu bir dönemde idarecilerin ne gibi konularla uğraştıkları da ayrıca dikkat çekicidir. Hem kendi tebaası olan halka karşı olabildiğince güvensizlik hem de bu öğrencileri şartların zor olduğu bir dönemde yatılı olarak her şeye rağmen eğitimlerini tamamlamalarına imkân vermek. Sene sonu geldiğinde bu öğrenciler hakkında yapılan ihbarların dikkate alınmadığı ve öğrencilerin mezun edildikleri görülmektedir. Edebiyat Fakültesi kısmında son sınıfa kayıtlı olan Kevork, Aram, Yervant ve Ohannes Efendilerin 1914-1915 eğitim sezonunda mezun olmuşlardır. ${ }^{117} \mathrm{Bu}$ dönem mezun olan 8 öğrencinin tamamı Darülmuallimîn-i Âliye kontenjanındandır ve dört tanesi de Ermeni kökenlidir.

\section{Maaşların Zamanında ve Tam Olarak Ödenmemesi, Yaşanan Problemler}

Darülfünun'un tüm fakülteleri savaş yıllarında büyük zorluklar çekmiştir. Savaş alanı genişledikçe ve süresi uzadıkça mali sıkıntılar artmıştır. Memurların maaşları aylarca ödenememiştir. Özellikle 200 kuruş civarında çok düşük ücretle çalışan müstahdemlerin durumu içler acısıdır. Şehirde baş gösteren "ğılayı isâr" [kıtlık] sebebiyle ve aynı zamanda cepheden gelen yaralı askerleri evlerinde misafir eden müstahdemler; maaşlarının ödenmemesi yüzünden zor günler yaşamışlardır. Darülfünun müdürü Salih Zeki Bey, nezaretten "pek ziyade zaruret çekmekte ve şayan-ı merhamet bir hal-i perişaniyeye duçar olan" bu insanların zaruri ihtiyaçlarını karşılamak üzere birikmiş maaşlarından iki aylığının ödenmesini talep etmiştir. Maarif Nezareti konuyu ancak Maliye Nezareti'ne iletmekle yetinmiş ve bu konuda bir şey yapılamamıştır. ${ }^{118}$

Savaş yıllarında öğretim üyeleri yarım maaş alıyorlardı, bazı dönemler bunu da alamayıp geriden takip ediyorlardı. Bu yüzden çok zor durumda kalan kalabalık nü-

117 Öğrencilerin künye bilgileri ve daha detaylı veriler için bakınız: M. Selçuk, İstanbul Darülfünunu Edebiyat Fakültesi (1900-1933), s. 234-241.

118 BOA, MF. ALY. 81-14, (1333 Ş 14); ayrıca Birinci Dünya Savaşı dönemi İstanbul'da halkın yaşadığı geçim sıkıntısı için bkz, Abdullah Saydam, "Birinci Dünya Savaşı'nda İstanbul Halkının Geçim Sıkıntısı", Belgelerle Türk Tarihi Dergisi, Sayı: 19, İstanbul 1998, s. 65-77; Büşra Karataşer, "Birinci Dünya Savaşı ve Mütareke Döneminde İstanbul'un İaşesi”, Kahraman Maraş Sütçü İmam Ünv. İIBF Dergisi, Y1l: 2013, Sayı: 2, s. 97-114. 
fusa sahip ailelere odun, buğday gibi yakacak ve gıda yardımı yapılıyordu. Edebiyat Fakültesi Tarih bölümü muallimlerinden Akçuraoğlu Yusuf üç farklı kurumda ders vermesine rağmen aylık eline 473 kuruş geçtiğini ve müderrislikten başka geliri olmadığı için geçim sıkıntısı çektiğini belirterek, hiç olmazsa birikmiş maaşından bir miktar ödeme yapılırsa temel ihtiyaçlarını karşılayabileceğini ifade etmiştir. ${ }^{119}$ Yine aynı bölümden Almanca muallimi Cemil Bey ise evleneceğini belirterek birikmiş maaşlarının ödenmesini talep etmiştir. ${ }^{120}$ Tarih-i Osmanî muallimi Efdalüddin Bey'de geçim sıkıntısı çektiğini ifade ederek kendisine yeni ders açılmasını teklif etmiştir. ${ }^{121}$ Bu dönemde Edebiyat Fakültesi'nde İçtimaiyat kürsüsünde Ziya Gökalp ile birlikte çalışan muallim muavini Ahmed Emin [Yalman] hatıralarında savaş günlerinde yaşadığı mali krizleri anlatmaktadır: ${ }^{122}$

"Sonra bir de şu mesele vardl: Harbin başında bütün maaşlar, esaslı bir tasarruf tedbiri diye yarım olarak veriliyordu. Kesintilerle beraber elime 400 kuruş kadar geçiyordu. Hâlbuki talebelik zamanında (Amerika'da doktora yapmıştır) aylığım kesintisiz 95 dolar yani 2500 kuruş olduğuna göre ben talebeliğimden üniversite hocalığına yükselirken, maaşım beşte bire inmişti. Geçinmek imkânsızdı"

Ahmed Emin geçim derdini aşmak için gazetecilik yapmış, yabancı basının temsilcilik görevlerini yürütmüştür.

\section{Darülfünun İle İlgili Diğer Gelişmeler}

Darülfünun için yeni yapılması planlanan ve arazisi dahi satın alınan bina savaş boyunca bir türlü yapılamamış̧ ${ }^{123}$ Mütareke döneminde ise adı geçen arsa satılmak zorunda kalmıştır. ${ }^{124}$ Aynı şekilde Emrullah Efendi zamanından beri gündemde olan Darülfünun kanunu savaş yıllarında Darülfünun'a özerklik verilecek şekilde tasarlanmış, tartışılmış ve öğretim üyelerinin görüşü alınmış ancak bir türlü meclisten

119 Yusuf Akçura'nın bir miktar ödeme yapılırsa "çok müteşekkir olacağım" şeklinde bitirdiği 1 Temmuz 1915 tarihli dilekçesi için bakınız: BOA, MF. MKT. 1210-31, (1333 Ş 24), lef 1.

120 BOA, MF. MKT. 1220-86, (1335 M 27).

121 Efdalüddin (Tekiner) Bey uzun bir dilekçe ile savaş zamanı çektiği sıkıntıları anlatmıştır. $B O A, M F$. ALY. 83-16, (1333 Za 20).

122 Ahmed Emin Yalman, Yakın Tarihte Gördüklerim ve Geçirdiklerim (1888-1918), c.1, Yenilik Basımevi, İstanbul 1970, s. 212.

123 Darülfünun binası ilgili krokiler ve planlar meclis toplantılarında gündeme gelmiş ve öğretim üyelerinden bina hakkında istedikleri özellikleri ayrıca yazılı olarak nezarete bildirmeleri kararlaştırılmıştır. İlgili toplantılar için bkz, IDF. EF. MMZD-II, Z.N.2, 16 Kanun-1 sani 1332; IDF. EF. MMZD-II, Z.N.5, 6 Şubat 1332; IDF. EF. MMZD-II, Z.N.6, 13 Şubat 1332; İ. Hakkı Baltacıoğlu, adı geçen arazinin Laleli sınırları içerisinde kalan Koska civarındaki binaların yangından sonra kamulaştırıldığından bahsetmektedir. Bkz, İ.Hakkı Baltacıoğlu, a.g.e., s. 209.

124 BOA, MV. 220-115, (1339 M 14); A. Siler, a.g.t., s. 154; İttihat ve Terakki Cemiyeti'nin Sapanca Gölü çevresinde bir Darülfünun Kolonisi yapmak fikri hakkında bkz, İ.Hakkı Baltacıoğlu, a.g.e., s. 209. 
geçerek kanunlaşamamıştır. ${ }^{125}$ Bu düzenleme ancak mütarekeden yaklaşık bir yıl sonra 11 Ekim 1919 tarihinde Darülfünun-ı Osmanî Nizamnamesi adıyla yürürlülüğe girmiştir. ${ }^{126}$

Darülfünun'da tüm bu zorluklar yaşanırken çok önemli reformlar da hayata geçirilmiştir. Yine savaşın etkisi ile askeri alanda had safhaya çıkan Almanya ile işbirliğinin sınırları eğitim alanında da etkisini göstermiştir. İttihatçıların da desteği ile Türkiye'de aktif görevlerde bulunan Alman misyon şefleri Türk eğitim sistemindeki Fransız etkisini azaltmak ve yerine Alman nüfuzunu yerleştirmek için epey çapa sarf etmişlerdir. ${ }^{127}$ İlk planda İstanbul'da bir Alman üniversitesi kurmayı hedefleyen bu çevreler savaş nedeni ile bunun imkânsız olduğu görünce bu sefer Darülfünun'da bir Alman ekolü oluşturmak için önemli çalışmalar yapmışlardır. Fen, Edebiyat ve Hukuk fakültelerinde olmak üzere yaklaşık 20 kadar Alman öğretim üyesinin savaş boyunca Türkiye'de istihdam edilmesi son derece önemli bir projedir. ${ }^{128}$ Aynı şekilde Almanya'ya gönderilen öğrenciler de bu projenin bir parçasıdır.

Darülfünun'da savaş dönemi uygulamalarından birisi de kızların yükseköğretim haklarını elde etme mücadelesidir. İttihat ve Terakki hükümetlerinin bu dönemde yaptıkları reformlar içerisinde; İnas Darülfünunu projesi şüphesiz çağın ilerisinde bir girişim olarak değerlendirilebilir. İngiltere'de Oxford Üniversitesinde kızların kabul tarihi 1920’lerdir. Maarif Nezareti ve Darülfünun yöneticileri üniversitenin kapılarını kadınlara açmak için bir takım girişimlerde bulunmuşlardır. Maarif Nezareti’nin kadınlar ile ilgili projelere öncelik vermesi şüphesiz dönemin şartları ile doğrudan bağlantılıdır. Savaşın olumsuz etkileri yöneticileri yeni arayışlara itmiştir. Erkek öğrenciler cephede savaşırken sınıflar boş kalmıştır. Nitekim Ethem Nejat bir yazısında

125 Maarif Nezareti “Darülfünun’a verilecek şekl-i umumiyeye nazaran bir kanun layihası tanziminin lüzumuna" dair 22 Mart 1332 [4 Nisan 1916] tarihli bir tezkere ile bu konunun meclislerde tartışılmasını istemiştir. Darülfünun nizamnamesi çalışmaları uzun süre devam etmiş, bu konuda birçok kez fakülte meclislerinden görüş alınmış ve bu iş için komisyonlar kurulmuştur. Özellikle Edebiyat Fakültesi'nden Ziya Gökalp, İsmayıl Hakkı, Köprülüzade Fuad, Faik Sabri, M. Ali Aynî, M. Emin gibi öğretim üyelerinin üzerinde çok durdukları bir konu olan Darülfünun muhtariyeti meselesi ve ilgili kanun Darülfünun-ı Osmanî Nizamnamesi adıyla ancak 1919 Ekim ayında çıkartılabilmiştir. Edebiyat Fakültesi'nin Darülfünun kanun çalışmaları ile ilgili raporu için bkz, BOA, MF. ALY. 109-77, (1336 M 5), lef 151; M. Ali Aynî de fakültenin gönderdiği 10 Mayıs 1332 [23 Mayıs 1916] tarihli mazbatadan bahsetmiştir. Bkz, Aynî, a.g.e., s. 52-53; İ.Hakkı Baltacıoğlu, a.g.e., s. 224; Fakülte meclisinde Darülfünun kanununun gündeme geldiği toplantılar şunlardır: IDF. EF. MMZD-II, Z.N.1, 3 Teşrin-i evvel 1334; IDF. EF. MMZD-II, Z.N.2, 7 Teşrin-i evvel 1334; IDF. EF. MMZD-II, Z.N.7, 16 Kanun-1 sani 1334; IDF. EF. MMZD-II, Z.N. 8, 28 Şubat 1334.

126 Darülfünun-ı Osmanî Nizamnamesi (DFON) için bkz, Düstur, II. Tertip, c. 11, s. 401-409.

127 Almanların savaş zamanı Türkiye'de eğitim faaliyetleri için bakınız: Kemal Turan, Türk-Alman Eğitim İlişkilerinin Tarihi Gelişimi, İstanbul 2000; Mustafa Gencer, Jöntürk Modernizmi ve "Alman Ruhu", 1908-1918 Dönemi Türk- Alman İlişkileri ve Eğitim, İstanbul 2003.

128 Birinci Dünya Savașı Yıllarında Darülfünun'da istihdam edilen yabancı öğretim elemanları ile ilgili bakınız: Emre Dölen, İstanbul Darülfünunu’nda Alman Müderrisler 1915-1918, İstanbul Bilgi Üniversitesi Yay., İstanbul 2013; Mustafa Selçuk, "Darülfünun Edebiyat Fakültesinde Yabancı Öğretim Üyelerinin Istihdamı (1915-1918)”, İ.Ü. Edebiyat Fakültesi Güney-Doğu Avrupa Araştırmaları Dergisi, Sayı: 19, Y1l: 2011, s. 57-110. 
bu duruma şu şekilde ifade etmiștir: "Harb-i umumi esnasında, gerek hükümet gerek erbab-ı maarif, hanımlarla daha ziyade iștigal eyledi. Pek çok meşâgil-i harbiye ve siyasiyeye rağmen kadın maarifi pek ilerledi. ${ }^{129 "}$

Maarif Nezareti, savaş koşullarını hafifletmek ve yapılan yatırımların boşa gitmemesi için kadınların eğitimine ehemmiyet vererek onlar üzerine titremiş ve kısa zamanda büyük mesafeler almak için devletin bütün imkânlarını seferber etmiştir. ${ }^{130}$ Önce serbest konferanslar ile kadınlar Darülfünun ile tanıştırılmış daha sonra bu dersler üniversite müfredatı şeklinde düzenlenerek planlı bir eğitim programına geçilmiştir. Kızlar için üç farklı branşta diploma veren bir yapı oluşturulmuştur. 19141919 yıllarında Darülfünun imkânları ile Darülfünun'a benzer bir eğitim sistemi benimsenmiștir. Buradaki dersleri Darülfünun öğretim elemanları vermiştir.

1914-1919 yılları arasında faaliyet göstermiş nev’i şahsına münhasır bir yükseköğretim kurumu olan İnas Darülfünunu, ${ }^{131}$ savaş boyunca süren eğitim öğretim döneminde Edebiyat, Fünun (Tabilyat ve Riyaziyat) şubeleriyle kızlara üniversite eğitimi vermiştir. Beş ylllı eğitim öğretim faaliyetleri süresince yaklaşı yüz elli kadar kız öğrenciyi kabul etmiş ve bu öğrencilerin de üçte birine üniversite diploması vermiştir. Zeynep Hanım Konağı'nda başlayan eğitim serüveni üç yll kadar Cağaloğlu'ndaki eski Lisan ve Hukuk Mektebi’nde devam etmiștir. Kapanıştan kısa bir süre önce tekrar Zeynep Hanım Konağı'na taşınmıştır.

\section{Öğrencilerin Mağduriyetlerini Gidermeye Yönelik Uygulamalar}

Sultanî, idadî ve yüksekokul öğrencilerinin silâhaltına alınması bu okullar mezun veremez duruma gelmiștir. Dolayısıyla sıralı olarak Darülfünuna ve diğer yüksekokullara yeni öğrenci kaynağı kesilmiştir. Bu tıkanıklığı biraz hafifletmek için bakalorya sınavlarında bazı değişiklikler yapılmıştır. 1914 yılı Bakalorya imtihanlarının katılımın düşük olmasından dolayı sınavın tekrarlanması ve ilk sınavda başarısız olanların da girmesi kabul edilmiştir. ${ }^{132}$ Yine 1916 yllından itibaren iki yıl süre ile lise mezunlarının sınavsız olarak fakültelere kabul edilmesine ${ }^{133}$ rağmen öğrenci sa-

129 Edhem Nejad, “Türkiye'de Kız Mektepleri ve Terbiyesi”, Türk Kadını, nr. 11, 17 Teşrin-i Evvel 13341918, s. 163-165.

130 Nafi Atuf da "bu devrin en ehemmiyetli maarif tahavvülü kız mekteplerinde görülür" demek suretiyle hükümetin cesaretine vurgu yapmıștır. Nafi Atuf Kansu, Türkiye Maarif Tarihi Hakkında Bir Deneme (II. Kitap), İstanbul 1932, s. 82.

131 İnas Darülfünunu hakkında ayrıntılı bilgi için bakınız: Ali Arslan, Mustafa Selçuk, Mehmet Nam, Türkiye’nin İlk ve Tek Kız Üniversitesi: İnas Darülfünunu (1914-1919), İdil Yay., İstanbul 2012.

13211 Tessrin-i evvel 1330 [24 Ekim 1914] tarihli kararname için bkz, BOA, MF. ALY. 71-95, (1332 Z 5); MF. ALY. 71-99, (1332 Z 5) ayrıca Mülâzemet Rüusu'nun (Bakalorya imtihanları) uygulanması gerektiği hakkında bkz, BOA, MF. ALY. 55-103, (1332 S 21).

133 BOA, I.DUİT. 18-73, (1334 C 12); Bakalorya imtihanlarında daha sonraki tarihlerde üç kez daha bu süre uzatılmıștır. Sırasıyla kanun metinleri için bkz, Mülâzemet Rüusu Nizamnamesi: $B O A$, I.DUİT. 60-1, (19 C 1331); MF. ALY. 55-103, (1332 S 21); Mülâzemet Rüusu İmtihanlarına Mütedair 19 Ce- 
yıları hiç artmamıştır. Darülfünun'un nasıl öğrencisiz kaldığı hem mezun sayılarında hem de yukarıda fakülteler kısmında ifade edilmişti. Maarif Nazırı Ahmet Şükrü Bey, Meclis-i Mebusan'da 1916 yılı bütçe görüşmeleri esnasında "Darülfünun'da ne kadar öğrenci bulunmaktadır?” sorusuna; tüm birimler dâhil sadece 450 civarında bir öğrenci kaldığı ifade etmiştir. ${ }^{134}$ Yine cepheden izinli olarak İstanbul'a gelen ve hocalarını ziyaret etmek için Darülfünuna uğrayan İhtiyat Zabiti İsmail Hakkı Efendi; “Darülfünun'da hemen hiç kimse yok gibi idi. Kimleri okutuyorlardı hocalar acaba? Askerlik çă̆ına yaklaşanlar bile vaktinden evvel talimgâhlara çağrılmaya başlanmış. Harp cephesinden bunlardan habersizdik" diyerek hayretini ve üniversitede yaşanan öğrenci kıtlığını dile getirmiştir. ${ }^{135}$

Mevcut okuyan öğrenciler içerisinde silâhaltına alınanların imtihanları tehir edilmiş ve Eylül imtihanlarına girmeleri sağlanmıştır. Maarif Nezareti, hizmet-i maksureye tabi kısa dönem öğrencilerin kayıtlarının silinmemesi ve onların terhisine kadar bilgilerinin muhafaza edilmesini maarif müdürlüklerine genelge olarak bildirmiştir. ${ }^{136}$

Savaş devam ederken özellikle taşrada devamsızlık yapan öğrencilerin durumu sorulmuştur. İlk planda Maarif Nezareti devamsızlık hakkında yapılacak işlemler konusunda okul müdürlerinin ve maarif müdürlerinin takdirine bırakılmıştır. ${ }^{137}$ Daha sonra bu konuda öğrencilerin mağdur olmaması adına özellikle Darülfünun ve mekâtib-i âliye öğrencileri için 1915 senesine mahsus olmak üzere mektebe başvurdukları tarihten itibaren devam şartının aranması kabul edilmiştir. ${ }^{138}$ Yine Haziran ayında gerçekleştirilen birinci devre imtihan-1 umumilerin sonuna kadar bütün ihtiyat zabit namzetlerinin tecil-i sevklerini yapılması konusunda askeri otorite ile birlikte karar verildiği ifade edilmiştir. ${ }^{139}$ Hatta bu konuda Sanayi-i Nefise Mektebi'nde öğrencilerin askere çağrılmaları hususu ortaya çıkınca ${ }^{140}$ Maarif Nezareti olaya müdahale ederek sınavlar bitmeden hiçbir öğrencinin gönderilmemesi gerektiği ifade

maziyelahir 1331 tarihli nizamnameye müzeyyel mevadd-ı nizamiye: $B O A, \dot{I} . D U \dot{I} T$. 18-73, (1334 C 2); Düstur, II. Tertip, c. 8, s. 897, diğer ek nizamnameler için ayrıca bkz: Düstur, II. Tertip, c.10, s. 588 ve BOA, I.DUİT. 18-71, (21 S 1338); Düstur, II. Tertip, c. 11, 446.

134 Meclis-i Mebusan Zabıt Ceridesi [MMZC], Devre: 3, İçtima Senesi: 2, c. 1, 28 Kanun-1 sani 1331, s. 540; Maarif Nazırı A. Şükrü Bey, sultanîlerin son sınıfında okuyan tüm öğrencilerin "hizmet-i maksureye” alındığını belirtmektedir. Bkz, MMZC, Devre: 3, İçtima Senesi: 3, c. 3, 5 Mart 1333-1917, s. 76-80.

135 İ. Hakkı Sunata, Gelibolu’dan Kafkaslara I. Dünya Savaşı Anılarım, 4. Baskı, İş Bankası Kültür Yay., İstanbul 2015, s. 227.

136 BOA, MF. HFS. 5-119.

137 BOA, MF. ALY. 80-30, (1333 В 16).

138 BOA, MF. ALY. 79- 3, (1333 C 10).

13925 Nisan 1915 tarihli genelge için bakınız: BOA, MF. MKT. 1208-30, (1333 C 10).

140 Sanayi-i Nefise Mektebi müdürlüğünün 1 Temmuz 1915 tarihli yazısı için bakınız: BOA, MF. ALY. 81-33, lef 1 . 
edilmiş böyle bir durum olduğunda derhal nezaretin bilgilendirilmesi istenmiştir. ${ }^{141}$ Yine silâhaltındaki öğrenci, memur ve muallimlerin devlete olan borçlarının terhis edilinceye kadar ertelenmesine karar verilmiştir. ${ }^{142}$

\section{Avrupa'ya Gönderilen Öğrencilerin Durumu}

Avrupa'ya giden öğrenciler de mağdur olmuştur. Özellikle düşman devlet statüsüne giren İngiltere, Fransa, daha sonraları İtalya gibi ülkelerde okuyan öğrenciler eğitimlerini yarıda bırakarak geri dönmek zorunda kalmışlardır. Bu öğrencilerin hangi nezaret adına gönderilmiş ise mecburi hizmet tazminatlarının devlet tarafından kanunlar dairesinde karşılanması kabul edilmiştir. ${ }^{143}$ Yine savaş zamanında ağırlıklı olarak Almanya'ya öğrenci gönderilmiş bir miktar da Avusturya Macaristan imparatorluğuna gönderilmiştir. Bu öğrenciler de gittikleri üniversitelerde büyük sıkıntılar çekmişlerdir. ${ }^{144}$ Türkiye'den ödemeler gecikmiş ve bazıları da seferberlik gereği geri çağrılmıştır. ${ }^{145}$

Ahmet Emin, Alman-Türk Yurdu verilerine dayanarak 1918'in sonlarında Almanya'da 2000'den fazla Türk öğrenci bulunduğunu ve bu öğrencilerin çeşitli Alman üniversitelerinde, teknik okullarda ve kolejlerde eğitim gördüklerini belirtmiştir. Öğrencilerin çoğu erkekti ama kız öğrencilerin de sayısı sürekli artıyordu. Yine 200 kadar kimsesiz Türk erkek çocuğu Almanya'da çeşitli endüstri kollarında çalışıyordu. ${ }^{146}$ Türkiye'de Almanca öğrenmek o günün modasıydı diyen Ahmet Emin, aileler çocuklarını askerlikten kurtarmak için Almanya'ya eğitime gönderdiklerini söylemiştir. ${ }^{147}$ Almanya hükümeti ve Türkiye'deki alman nüfuz çevreleri de bu öğrenci transferini desteklemiştir.

\section{Savaş Sonunda Mağduriyetleri Gidermeye Alınan Kararlar}

Savaş meydanlarında şehit olan öğrenciler ve öğretmenler için çok fazla yapılacak bir şey kalmamıştır. Ancak maalesef Türkiye'de Birinci Dünya Savaşı ile ilgili tüm

141 Maarif Nezareti'nin 5 Temmuz 1915 tarihli cevabi yazısı için bakınız: BOA, MF. ALY. 81-33, lef 2.

142 BOA, MV. 195-77.

14316 Eylül 1914 tarihli Meclis-i Vükelâ kararı için bakınız: BOA, $M V$. 192-29.

144 Avrupa'ya eğitim görmek için giden ve savaş dönemi eğitimleri aksayan kız öğrencilerin serüveni için bakınız: Güldane Çolak, Avrupa'da Osmanlı Kızları, Heyemola Yay., İstanbul 2013, s. 56-109.

145 Almanyàya gönderilen öğrencilerin savaș boyunca yașadığı problemler için bakınız: Lale Uçan, "Problems of Turkish Students in Germany During the First World War ", I. Uluslararası Tarihi ve Kültürel Yönleriyle Türk-Alman İlişkileri Sempozyumu (8-10 Ekim 2009), Bildiriler Kitabı, Konya Valiliği Yay., Konya 2010, s. 727-735.

146 Almanya'ya gönderilen yetimler ile ilgili geniş bilgi için bakınız: Nazan Maksudyan, "Mavi Kep ve Pelerin: Cihan Harbi Ylllarında Almanya'da Osmanlı Yetimleri”, Toplumsal Tarih, Sayı: 243, Mart 2014, s. 22-27.

147 Ahmed Emin, Turkey in the Worl War, p. 227-228. 
cephelerde zayiat rakamları hala tartışmalı ve net sayıların olmaması nedeniyle hangi cephede ne kadar öğrenci, tahsilli gençlik şehit olduğunu tespit etmek bugünkü eldeki verileler ile tam mümkün görünmemektedir.

Daha savaş devam ederken Maarif Nezareti'nin Darülfünun'a talep ettiği bir husus vardır. Almanya'da Heidelberg Üniversitesi, Cihan Harbi'ne iştirak eden kendi öğrencilerinden oluşan bir albüm hazırlamıștır. Türkiye'ye gönderilen bu eser Maarif Nezareti tarafından Darülfünan'a havale edilmiş ve "Darülfünunca da böyle bir mecmuanın neşri șayan-ı temenni” edilmiștir. Eğer üniversite yönetimi böyle bir eser hazırlasa idi şüphesiz isimsiz kahramanlar hakkında daha fazla bilgiye sahip olacaktık. En azından Darülfünun'dan savaşa katılmış öğrencilerin kesin sayısını tespit edebilirdik. Çok zayıf bir ihtimal ile de böyle bir eser hazırlandı ancak gün yüzüne çımadı, ya da ulaşmadı.

Birinci Dünya Savaşı sona erdiğinde Çanakkale Cephesi dâhil savaşın ortaya çıkardığı tahribat biraz netleşmeye başlamıştı. Bir yandan kısa dönem yükümlüleri olan öğrenciler, öğretmenler terhis edilirken bir yandan da mağduriyetler ile ilgili Maarif Nezareti'ne dilekçeler gelmeye başlamıştı. Hatta bu dilekçeler Cumhuriyet'in ilk yıllarına kadar fakülte idarelerine gelmeye devam etmiştir. ${ }^{148}$ Maarif Nezareti münferiden bu taleplerle ayrı ayrı ilgilenmek yerine hem bir standart yakalama hem de adil bir çözüm bulabilmek için savaşa katılan bütün tahsilli nesil için bazı tedbirler almıştır. Bu tedbirler öğretmen ve öğrencilerin maaş, terfi, sınıf kaybı, mecburi hizmet, devamsızlık gibi mağduriyetlerine çare olacak türden iyileştirmeler idi. Nezaretin en yetkili ve üst düzey danışma ve karar alma birimi olan Meclis-i Maarif-i Kebir'in gündemine gelen bu konu üzerine 10 Aralık 1918'de yapılan toplantıda orta, lise ve yüksekokul mezun, müdavim ve öğretmenlerle ilgili oybirliği ile 14 maddelik bir talimatname hazırlanmış ve bu maddeler nezaret tarafından merkez ve taşradaki tüm birimlere gönderilmiştir. ${ }^{149}$

18 Aralık 1918'de kurumlara gönderilen talimatnamenin ilk maddesi çok önemlidir. Ancak muhtemelen yukarıdaki albüm konusunda olduğu gibi burada yapılması istenen hususlar Mütareke'nin kargaşalı ve daha felaketli günlerinde unutulup gitmiştir. Birinci maddede çok önemli bir konu ele alınır. Öncelikle vatan için savaş meydanlarında şehit düşmüș öğrenciler ve öğretmenler adına her kurum kendi binası içerisinde veya girişinde "şüheda-yı muhteremin ibka-yı namları" için yani şehitlerin isimlerinin sonsuza kadar unutulmaması için okul binalarına birer levhada isimlerinin yazılması istenmiştir. Bu konuda 1919 yılın mezuniyet döneminde Darülfünun Hukuk Fakültesi'nde bir takım hazırlıklar olduğu anlaşılmaktadır. Hukuk öğrencisi İsmail Hakkı Sunata'nın anlatımına göre 1919'un Eylül ayında mezun olan öğren-

148 Edebiyat Fakültesi üçüncü sınıfında iken askere alınan Süleyman Efendi'nin 1926'da yazdığı dilekçe için bakınız: İ.Ü. Edebiyat Fakültesi Arşivi: IDF. EF. MMZD-III, 7 Ağustos 1926.

149 BOA, MF. MKT. 1237-7, (1337 M 14). 
ciler bir çay partisi düzenlemiş ve burada fakülte reisi Selahattin Bey bir konuşma yapmıştır; konuşmasında mütareke dönemi mezunlarının çok çile çektiğini, harpten öncesi ile şimdiki mezunlar arasında çok fark olduğunu ve birçok öğrencinin harpte kaybedilmiş olduğunu ve bu şehitlerin kimlikleri tespit edilerek mermer üzerine adlarının yazılarak Darülfünun'un münasip bir yerine asmak istediklerini belirtmiştir. ${ }^{150}$ Maalesef böyle uygulama günümüze ulaşmamıştır. Belki kısmen bu uygulamayı yapan kurumlar vardır. Onlar da muhtemelen diğer tarihi eserler gibi zayii olmuş günümüze ulaşmamıştır. Her kurumda böyle bir şuurla hazırlamış defterler, levhalar, mermerler olsaydı bugünkü bilgilerimiz daha sağlıklı olurdu.

Meclis-i Kebir-i Maarif, silâhaltına alınan ve savaşta hayatta kalmayı başarıp geri dönen eğitimli gençlik ile ilgili özetle şu kararları almıştır:

- Askere alınan öğrenciler arasında gündüzlü okumaya imkânı yoksa yatılı okullarda bunlara öncelik sağlanması,

- Sultanî öğrencilerinden öğretmen okullarına geçmek isteyen olursa yine bunlara öncelik tanınması,

- Öğretmen okullarında iken veya yatılı okullarda iken askere alınan öğrenciler geri geldiklerinde öğretmenlik dışında farklı bir tercihte bulunurlarsa bu gibilerin mecburi hizmetten istisna tutulması

- Sultanîlerin 10.,11. ve 12. sınıf öğrencilerinin her türlü kayıplarını giderecek önlemlerin alınması ve onlara bütün kontenjanlarda öncelik sağlanması.

- Avrupa'da tahsilde iken askerlik hususunda zorluk çekenlere eğitimlerini bitirinceye kadar zaman tanınması,

- Talimatnamenin 12. maddesi Darülfünun öğrencileri için yazılmıştır. ${ }^{151}$ Darülfünun'un çeşitli fakültelerinde iken silâhaltına alınan öğrenciler hangi safhada kalmışlar ise döndüklerinde kaldıkları yerden sadece imtihanlara girerek bir yıl içerisinde mezun olma hakkı tanınmış aynı şekilde sınav ve ders programlarında yapılan değişiklerden de muaf tutulmuşlardır.

Meclis-i Kebir-i Maarif'in aldığı kararlar öğrenci, mezun ve öğretmenlerin çeşitli şekillerde mağdur oldukları bazı durumları kısmen telafi edecek şekildedir. Özellikle öğrenciler için giremedikleri derslerin sınavlarına bir sene içerisinde girmek usulüyle ilgili bölüm ve okullardan mezun edilerek meslek sahibi olabilecekleri birer diploma almayı hak kazanmışlardır. Tabii ki bütün öğrenciler okullarına geri dönememiştir. Birçok öğrenci babasıyla, abisiyle, yakın akrabaları ile birlikte bazen farklı bazen de

150 İ. Hakkı Sunata, İstanbul'da İşgal Yılları, s. 57.

151 Darülfünun Edebiyat Fakültesi Talebe Rehberi, “16 Şubat- 16 Haziran 1335”, Evkaf Matbaası 1335, s. 7-8. 
aynı cephelerde savaşmıştır. Kimisi esir düşmüş, kimisi de şehit olmuştur. Geri dönenler içerisinde yakınlarını kaybedenler ailelerini korumak, ocaklarını devam ettirebilmek için memleketlerine gitmek zorunda kalmışlardır. Ailelerini geçindirmek zorunda olanlar bu haklardan yararlanamamışlardır. Örneğin Darülfünun Hukuk öğrencisi olan ve çeşitli cephelerde savaştıktan sonra İstanbul'a dönen İsmail Hakkı Sunata, ailesine bakmak zorunda olduğu için hâkim olarak tayini çıtığı halde ailesini bırakıp taşraya gidememiştir. ${ }^{152}$

\section{Sonuç}

Diğer nezaretler ile birlikte özellikle Dâhiliye Nezareti seferberliğin organizesinde ve iç güvenliğin sağlanmasında kolluk kuvvetleri ile özellikle de Emniyet-i Umumiye Müdüriyet-i Umumiyesi ve Polis Müdüriyet-i Umumiyesi gibi birimleri ile Başkumandanlık Vekâletine azami derecede yardımcı olmuştur. Bahriye Nezareti dâhil tüm bakanlıklar kendi sorumluluklarına giren alanlarda savaşın idamesi için hükümetle işbirliğine gitmiştir. İç ve dış güvenlikten sorumlu otoritelerden sonra en fazla yük Maarif Nezareti'ne düşmüştür. İdarecisi, memurları, müstahdemleri ve eğitim kadroları ile savaşa destek verdiği gibi birçok okul da başta hastane olarak çeşitli gerekçelerle işgal edilmiştir. Osmanlı ordusunun insan kaynağını okuma yazma oranı düşük olan kırsal kesimden sonra en büyük kalemi mevcut öğrenciler ve eğitim görmüş mezunlar oluşturmuştur. Güç, Genç dernekleri gibi yarı sivil dernekler de yine maarif teşkilatı kaynaklarını kullanmıştır. Öğrenciler ile ilgili şartlar o kadar ağırlaşmıştır ki eğitim öğretim kurumlarında öğrenci ve muallim eksikliğinden dolayı düzenli eğitim yapılamamıştır. Birçok okul kısmi olarak tatil edilmiş imtihanlar zamanında yapılamamıştır. Yine eğitim tarihi açısında son derece önemli verileri içeren istatistikler düzenli tutulamamıștır. Osmanlı maarif sisteminin en kapsamlı ve geniş istatistiği 1913-1914 eğitim dönemine aittir. Savaş yıllarında bu veriler derlenememiştir. Savaşın felç ettiği sosyal ve iktisadi hayatın zorlukları arasında aileler, çocuklarını yatılı kurumlara vermek için epey uğraş vermiştir. Çünkü en temel ihtiyaçları karşılamak için başka çare bulunmamaktadır. Yine savaş ortamında kurumlar öğrencilerinin "hangi cephede, esir mi, kayıp mı, săg mı şeklinde” akıbetini araştırma ihtiyacı duymuşlardır.

II. Meşrutiyetten beri İttihatçıların idealleri olan yeni neslin, yeni kadının inşası sürecinde eğitim kurumlarında yapmak istedikleri reformlar genel itibariyle "ahval-i hazıra" nedeniyle eksik kalmıştır. Yıllarca gündemde tutulan ve kısmen gerçekleştirilen Darülfünun reformu savaş nedeni ile yeterli netice vermemiştir. Genç neslin bir anda büyük kitleler halinde silâhaltına alınması ve kişilerin yarıdan fazlası zayiat olarak kayıtlara geçmesi aynı şekilde yaralı ve hasta olarak dönenlerin de kısa sürede

152 İ. Hakkı Sunata, İstanbul'da İsgal Yılları, s. 61-63. 
iyileşememeleri veya sakat kaldıklarından dolayı engelli olmaları Türk toplumunun görünmeyen kaybı olarak tarihe geçmiştir. Yeni kurulan devletin en fazla ihtiyaç duyduğu eğitimli ve genç neslin büyük bir miktarı genel savaşta yitirilmişti. Yine yıkılan şehirler, tahrip edilen eğitim müessesleri, mütareke sonrası yaşanan işgaller ve savaşın ağır ekonomik sonuçları Türkiye'nin yıllarca belini doğrultamamasına neden olmuştur. Yine 20. yüzyılın en büyük dramı olan zorunlu göçlerle yaşanan tehcir, muhaceret ve iltica, milli sınırlar dışında kalma gibi etnik yapıyı baştan aşağı değiştiren sosyolojik ve psikolojik travmalar ülkenin geleceğini uzun seneler esir almıştır. Savaşların yeni doğan kayıp nesiller üzerinde bıraktığı tesirler, yerlerinden yurtlarından ve emeklerinden edilen nesillerin intikam, milliyetçilik ve diğer dini sebepler nedeniyle biriktirdikleri elemler eğitim sistemine ve ders kitaplarına yansımıștır.

$\mathrm{Bu}$ çalışmada savaşın hep olumsuz yanlarını ve eğitime olan zararlarını ortaya koymaya çalıştık, ancak sınırlı olsa da savaşın bazı olumlu yönleri de bulunmaktadır. Yukarıdaki satırlarda ifade edildiği gibi savaş şartlarında kızların eğitimi konusunda önemli mesafeler alındığı gibi sağlık alanında da yine salgın hastalıklardan dolayı tüm Anadolu'nun büyük zarar gördüğü bilinmektedir. Ordunun kapasite olarak büyümesi ve sıhhi hizmetlerin de artması neticesinde, askeri birliklerin en ücra köşelere kadar nüfuz etmesi ve bazen birkaç yıl bu bölgelerde konuşlanması yöre halkı için bir yandan (iaşe açısından) büyük yük olsa da askeri birlikler ile birlikte tabip subayların da köylere kadar ulaşması yöre insanı için bulunmaz fırsattır. Çünkü uzman bir hekimin karşısına çıkmak için o günün şartları ile vilayet merkezine bin bir zahmet ile gitmesi gerekirken, askerî hekim köylünün ayağına gelmiştir. Nitekim Sıhhiye umum müdür vekili Dr. Adnan [Adıvar] Bey meclis görüşmelerinde bu hususa dikkat çekmiştir ${ }^{153}$.

Sonuç olarak eğitim kurumları ve kadroları, savaş boyunca bir yandan vatan savunmasını ve ordunun taleplerini birinci önceliğe almak duygusu ile hareket ederek, bir yandan da bütün imkânsızlıklara rağmen eğitimin sürdürülmesi gayreti içinde olmuşlardır. Öğrenciler ise kendilerinden beklenenin üzerinde fedakârlıkta bulunmuşlardır.

153 MMZC, 3. Dönem, 49. Birleşim, 5 Mart 1333/1917, s. 48. 


\title{
KAYNAKÇA
}

\author{
Başbakanlık Osmanlı Arşivi (İstanbul) \\ Maarif Nezareti Evrakı \\ Mektubî Kalemi Belgeleri (MF. MKT) \\ Tedrisat-1 Aliye Dairesi (MF. ALY) \\ Dâhiliye Nezareti Evrakı \\ Hariciye Nezareti Evrakı \\ Meclis-i Vükela Mazbataları (MV) \\ İradeler Tasnifi
}

\section{İstanbul Üniversitesi Edebiyat Fakültesi Arşivi}

Darülfünun Edebiyat Fakültesi Meclis-i Müderrisîn Zabıt Defteri II, (IDD. EF. MMZD-II)

Darülfünun Edebiyat Fakültesi Meclis-i Müderrisîn Zabıt Defteri III, (IDF. EF. MMZD-III )

Darülfünun Edebiyat Şubesi Künye Defteri (1329-1330), nr. 1-8/4 (15).

Darülfünun Ulum-ı Edebiye Şubesi Künye Defteri - II (1329-1330), nr. 1-8/5 (16).

T.C. İstanbul Darülfünun Talebe Rehberi, 1340-1341, Yeni Matbaa, İstanbul 1340.

Darülfünun Edebiyat Fakültesi Talebe Rehberi, “16 Şubat- 16 Haziran 1335”, Evkaf Matbaası 1335.

\section{Araştırma İnceleme Eserler}

Ahmed Emin, Turkey in the World War, Yale Unv. Press, New Haven, 1930.

Akgün, Seçil-ULUĞTEKIN, Murat, Hilâl-i Ahmer'den Kızılay'a, Cilt: I, Ankara 2000.

Akın, Yiğit, Gürbüz ve Yavuz Evlatlar: Erken Cumhuriyet'te Beden Terbiyesi ve Spor, İletişim Yay., İstanbul 2005.

Alkan, Mehmet Ö., Tanzimat'tan Cumhuriyet’e Modernleşme Sürecinde Eğitim İstatistikleri, Ankara 2000.

Arslan, A., Selçuk, M., Nam, M, Türkiye’nin İlk ve Tek Kız Üniversitesi: İnas Darülfünunu (1914-1919), İdil Yay., İstanbul 2012.

Ateș, Sanem Y., Asker Evlatlar Yetiştirmek: II. Meşrutiyet Dönemi’nde Beden Terbiyesi, Askerî Talim ve Paramiliter Gençlik Örgütleri, İletişim Yay., İstanbul 2012.

Aynî, M. Ali, Darülfünun Tarihi, İstanbul 1927.

Bakar, Bülent, Ermeni Tehciri, Atam Yay., Ankara 2009.

Baltacıoğlu, İ. Hakkı, Hayatım, (yay. haz. Ali Y. Baltacıŏlu), İstanbul 1998.

Baran, Tülay A., “Çanakkale Savaşında Hukuk İhlalleri”, Atatürk Araştırma Merkezi Dergisi, Sayı: 73, Cilt: 25, Mart 2009. 
Beşikçi, Mehmet, “İhtiyat Zâbiti’nden Yedek Subay'a: Osmanlı'dan Cumhuriyet’e Bir Zorunlu Askerlik Kategorisi Olarak Yedek Subaylık ve Yedek Subaylar 1891-1930 ", Tarih ve Toplum Yeni Yaklaşımlar, Sayı: 13, Güz 2011, s. 45-89.

Beşikçi, Mehmet, Birinci Dünya Savaşı'nda Osmanlı Seferberliği, İş Bankası Kültür Yay., İstanbul 2015.

Çapa, Mesut, Kızılay (Hilâl-i Ahmer) Cemiyeti (1915-1925), Ankara 2010.

Çiçek, Kemal, Ermenilerin Zorunlu Göçü (1915-1917), TTK Yay., Ankara 2005.

Çolak, Güldane, Avrupa'da Osmanlı Kızları, Heyemola Yay., İstanbul 2013.

Dölen, Emre, İstanbul Darülfünunu’nda Alman Müderrisler 1915-1918, İstanbul Bilgi Üniversitesi Yay., İstanbul 2013.

Edhem Nejad, “Türkiye'de Kız Mektepleri ve Terbiyesi”, Türk Kadını, nr. 11, 17 Teșrin-i Evvel 1334-1918, s. 163-165.

Er, Hamit, Medreseden Mektebe Geçiş Sürecinde Darülhilafe Medreseleri, İstanbul 2003.

Erdemir, Lokman, Çanakkale Savaşı: Siyasi, Askeri ve Sosyal Yönleri, Gökkubbe Yay., İstanbul 2009.

Erickson, Edward J., Büyük Hezimet: Balkan Harpleri’nde Osmanlı Ordusu, (çev. Gül Ç. Güven), İş Bankası Kültür Yay., İstanbul 2013.

Erickson, Edward J., Size Ölmeyi Emrediyorum! Birinci Dünya Savaşı’nda Osmanlı Ordusu, 3. Baskı, (çev. M. Tanju Akad), Kitap yayınevi, İstanbul 2011.

Erişirgil, M. Emin, “Ziya Gökalp”, Ülkü, Sayı: 55, İstanbul, Kanun-ı sani 1944.

Erşan, Mesut, “Çanakkale Muharebelerinde Savaş Hukuku İhlalleri”, Atatürk Araştırma Merkezi Dergisi, Sayı: 73, Cilt: 25, Mart 2009, s. 164-179.

Esenkaya, Ahmet, "Çanakkale Muharebelerinde Cephede ve Cephe Dışında Sağlık Hizmetleri”, Çanakkale Araştırmaları Türk Yıllı̆̆ı, Yıl: 9, Sayı: 10-11, Bahar-Güz 2011, s. 25-70.

Gencer, Mustafa, Jöntürk Modernizmi ve "Alman Ruhu”, 1908-1918 Dönemi Türk- Alman İlişkileri ve Eğitim, İstanbul 2003.

Halaçoğlu, Yusuf, Ermeni Tehciri, BKY Yay., İstanbul 2004.

Hankey, Donald, A Student in Arms, New York 1917.

Hurts, Steve, The Public Schools Battalion in the Great War, Pen \& Sword Books, South Yorkshire 2007.

İhsanoğlu, Ekmeleddin, Darülfünun: Osmanlida Kültürel Modernleşmenin Odă̆l, c. I ve II, Ircica Yay., İstanbul, 2010.

İrtem Süleyman K., Meşrutiyetten Mütarekeye (1909- 1918), (Haz. O. S. Kocahanoğlu), Temel Yay., İstanbul 2004.

Kafadar, Osman-Esenkaya, Ahmet, "Çanakkale Savaşlarında Kaybedilen Eğitim Görmüş Nesiller Üzerine Düşünceler ve Öneriler”, Çanakkale Araştırmaları Türk Yıllı̆̆l, Sayı: 2, Mart 2004, s. 135-161.

Kansu, Nafi Atuf, Türkiye Maarif Tarihi Hakkında Bir Deneme (II. Kitap), İstanbul 1932. 
Karacakaya, Recep, Türk Kamuoyu ve Ermeni Meselesi (1908-1923),Toplumsal Dönüşüm Yay., İstanbul 2005.

Karataşer, Büşra, “Birinci Dünya Savaşı ve Mütareke Döneminde İstanbul'un İaşesi”, Kahraman Maraş Sütçü İmam Ünv. İIBF Dergisi, Yıl: 2013, Sayı: 2, s. 97-114.

Maarif-i Umumiye Nezareti, İstanbul Darülfünunu Talimat, İstanbul 1329.

Maksudyan, Nazan, “Mavi Kep ve Pelerin: Cihan Harbi Yıllarında Almanya'da Osmanlı Yetimleri”, Toplumsal Tarih, Sayı: 243, Mart 2014, s. 22-27.

Orhonlu, Cengiz, "Edebiyat Fakültesi'nin Kuruluşu ve Gelişmesi (1901-1933) Hakkında Bazı Düşünceler”, Cumhuriyetin 50. Yılına Armağan, İstanbul 1973.

Osmanlı Belgelerinde Çanakkale Muharebeleri I ve II, TC. Başbakanlık Devlet Arşivleri Gen. Müd., Ankara 2005.

Osmanlı Hilâl-i Ahmer Cemiyeti 1335 Senesinde Münakıd Hilâl-i Ahmer Meclis-i Umumisi Heyet-i Muhteremesine Takdim Edilen 1330-1334 Senelerine Ait Merkez-i Umumi Raporu, Matbaa-i Orhaniye, İstanbul 1335.

Özbay, Kemal, Türk Asker Hekimliği Tarihi ve Asker Hastaneleri, c. 1, İstanbul 1976.

ÖZBAY, Kemal, Türk Asker Hekimliği Tarihi ve Asker Hastaneleri, c. 2, İstanbul 1976.

Sabah, İsmail, “Çanakkale Savaşlarının Eğitim Kurumuna Etkisi (1915-1916)”, Çanakkale On Sekiz Mart Üniversitesi, Eğitim Bilimleri Enstitüsü, Yayınlanmamıș Yüksek Lisans Tezi, Çanakkale 2013.

Saydam, Abdullah, "Birinci Dünya Savaşı'nda İstanbul Halkının Geçim Sıkıntısı”, Belgelerle Türk Tarihi Dergisi, Sayı: 19, İstanbul 1998, s. 65-77.

Selçuk, Mustafa, "Darülfünun Edebiyat Fakültesinde Yabancı Öğretim Üyelerinin İstihdamı (1915-1918)”, İ.Ü. Edebiyat Fakültesi Güney-Doğu Avrupa Araştırmaları Dergisi, Sayı: 19, Yll: 2011, s. 57-110.

Selçuk, Mustafa, Hedef Şehir İstanbul, Çanakkale Geçildi mi?, Emre Yay., İstanbul 2005.

Selçuk, Mustafa, İstanbul Darülfünunu Edebiyat Fakültesi (1900-1933), Atam Yay., Ankara 2012.

Sezer, Cemal, “Birinci Dünya Savaşı'nda Hilâl-i Ahmer Cemiyeti’nin Sağlık Alanındaki Faaliyetleri, History Studies, Volume: 4, Issue: 4, November 2012, s. 373-384.

Shaw, Stanford J., Birinci Dünya Savaşı’nda Osmanlı İmparatorluğu: Birinci Cilt, Savaşa Giriş, Terc.: Beyza S. Aydaş, Türk Tarih Kurumu Yay., Ankara 2014.

Sunata, İ. Hakkı, Gelibolu'dan Kafkaslara I. Dünya Savaşı Anılarım, 4. Baskı, İş Bankası Kültür Yay., İstanbul 2015.

Sunata, İ. Hakkı, İstanbul’da İşgal Yılları, 3. Baskı, İș Bankası Kültür Yay., İstanbul 2009.

Taşkıran, Cemalettin, “Çanakkale Savaşlarında İtilaf Devletlerinin Hasta ve Yaralılarımıza Saldırıları”, Çanakkale Araştırmaları Türk Yıllı̆̆ı, Sayı: 1, Mart 2003, s. 103-113.

Tetik, Ahmet-Güzel, M. Şükrü, Osmanlılara Karşı İşlenen Savaş Suçları (1911-1921), İș Bankası Kültür Yay., İstanbul 2013. 
Tunaya, Tarık Zafer, Türkiye’de Siyasi Partiler, c. 3, İletişim Yay., İstanbul 2000.

Turan, Kemal, Türk-Alman Eğitim İlişkilerinin Tarihi Gelişimi, İstanbul 2000.

Turan, Ömer, “Turkish Historiography of the First Word War", Middle East Critique, Vol. 23, No: 2, 2014, p. 241-257.

Uçan, Lale, "Problems of Turkish Students in Germany During the First World War", I. Uluslararası Tarihi ve Kültürel Yönleriyle Türk-Alman İlişkileri Sempozyumu (8-10 Ekim 2009), Bildiriler Kitabı, Konya Valiliği Yay., Konya 2010, s. 727-735.

Uşaklıgil, H. Ziya, Saray ve Ötesi, (Haz. N. Özmel Akın), İstanbul 2003, s.725.

Ünver, A. Süheyl, Birinci Cihan Harbinde Tip Fakültesi, İstanbul 1952.

Yalman, A. Emin, Yakın Tarihte Gördüklerim ve Geçirdiklerim (1888-1918), c.1, Yenilik Basımevi, İstanbul 1970.

Zengin, Zeki S., Medreseden Darülfünun'a Türkiye’de Yüksek Din Eğitimi, Adana 2009. 
